VOL. 7

JUNE, 1933

No. 12

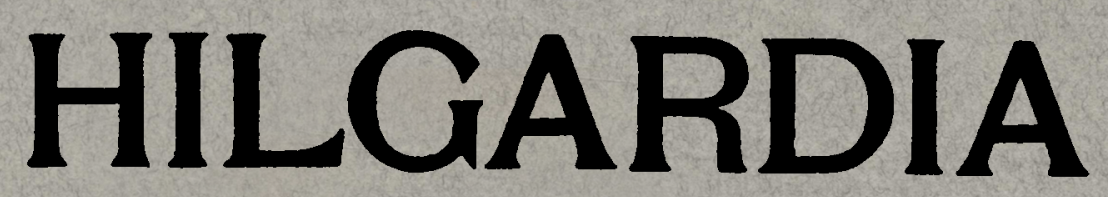

A Journal of Agricultural Science

PUBLISHED BY THE

California Agricultural Experiment Station

CONTENTS

The Biology of the Bean Thrips

STANLEY F. BAILEY

UNIVERSITY OF CALIFORNIA PRINTING OFFICE

BERKELEY, CALIFORNIA 


\title{
HILGARDIA
}

\author{
A JOURNAL OF AGRICULTURAL SCIENCE \\ PUBLISHED BY THE
}

CALIFORNIA AGRICULTURAL EXPERIMENT STATION

VOL. 7

JUNE, 1933

No. 12

\section{THE BIOLOGY OF THE BEAN THRIPS ${ }^{1}$}

STANLEY F. BAILEY2

Despite the great amount of research being done in the various orders, a study of the biology of the insects belonging to the order Thysanoptera still offers a fertile field. The life histories of many of these minute insects are still unknown; also a comparison of their various habits and activities presents extremely interesting material for speculation, emphasizing the need for detailed work of an exhaustive nature before the phylogeny of the group can be clarified. Doubtless the small size and elusive habit of the thrips, in addition to difficulties encountered in rearing and handling them, have been obstacles to the study of this group.

The bean thrips has become, in recent years, an increasingly important pest of several commercial crops, particularly in the dry interior valleys and nonirrigated sections of California. The problem presents several very interesting phases of an ecological nature and it is the twofold purpose of this paper to make the relationships of the group more perspicuous and, while not treating directly of control measures, to present information upon which a basis for future control might be established.

\section{SYNONYMY AND DESCRIPTION}

Synonymy.-Fortunately, perhaps, in contrast with many important insect pests, the history of the bean thrips is not very long nor the synonymy highly involved.

The first record of this thrips seems to be in 1895 when it was reported as collected in Yuba County, California, in November, 1894. Mr. G. W. Harney collected two specimens at this time on an orange leaf. It was on one of these specimens that Theodor Pergande's original description (Pergande, 1895) was based.

\footnotetext{
1 Received for publication July 13, 1932.

2 Junior Entomologist in the Experiment Station.
} 
No further record of the bean thrips is found until 1902 when Hinds redescribed this species from the one female specimen deposited in the Division of Entomology in Washington, D. C., by Mr. Harney in 1894. The male was not known and no knowledge of the life history was to be had at this time. Hinds (1902) changed the specific name from fasciata of Pergande to fasciatus, as he stated:

"Thrips is a Latin name derived from the Greek, meaning a woodlouse, and is in the singular number and masculine gender, as will be also all generic names of which it forms the termination."

Miss S. M. Daniel (1904) recorded five new species of Thysanoptera from California, in addition to Frankliniella occidentalis (Perg.), $\boldsymbol{F}$. tritici (Fitch), Thrips tabaci Lind., and Heliothrips fasciatus Perg., which had already been reported from this state. Among the new species was Caliothrips woodworthi which was fully described. However, Caliothrips woodworthi was made synonymous with Heliothrips fasciatus Perg. by Moulton (1907).

A brief description of the bean thrips was given by D. L. Crawford (1909) in the Pomona Journal of Entomology.

O. E. Bremmer, in 1910, listed the bean thrips under an incorrect genus as Euthrips fasciatus.

A new genus, Hercothrips, was erected by J. D. Hood (1927) who made Heliothrips striatus Hood the genotype. Sixteen species in all were removed from the genus Heliothrips and placed in the new genus Hercothrips. Heliothrips fasciatus Pergande was among those removed and so it is now synonymous with Hercothrips fasciatus (Perg.).

Description of the Bean Thrips.-The order Thysanoptera is divided into two suborders, the Terebrantia and the Tubulifera; the former has a sawlike ovipositor, while in the latter the terminal abdominal segment is tubelike with no ovipositor. Hercothrips fasciatus (Perg.) belongs to the suborder Terebrantia and the family Thripidae on the basis of such characters as down-turned ovipositor, 8-segmented antennae, and conical formation of the last abdominal segment of the female. And, further, following the classification of J. R. Watson (1923), H. fasciatus was placed in the genus Heliothrips since the wings are fully developed, the fore wings being without knoblike bristles, and the second segment of the antennal style being much longer than the first. However, Hood (1927) placed fasciatus in the genus Hercothrips on the basis of the costal fringe of bristles on the wings, the forked trichomes of the antennal segments, and the closely approximated hind coxae. 


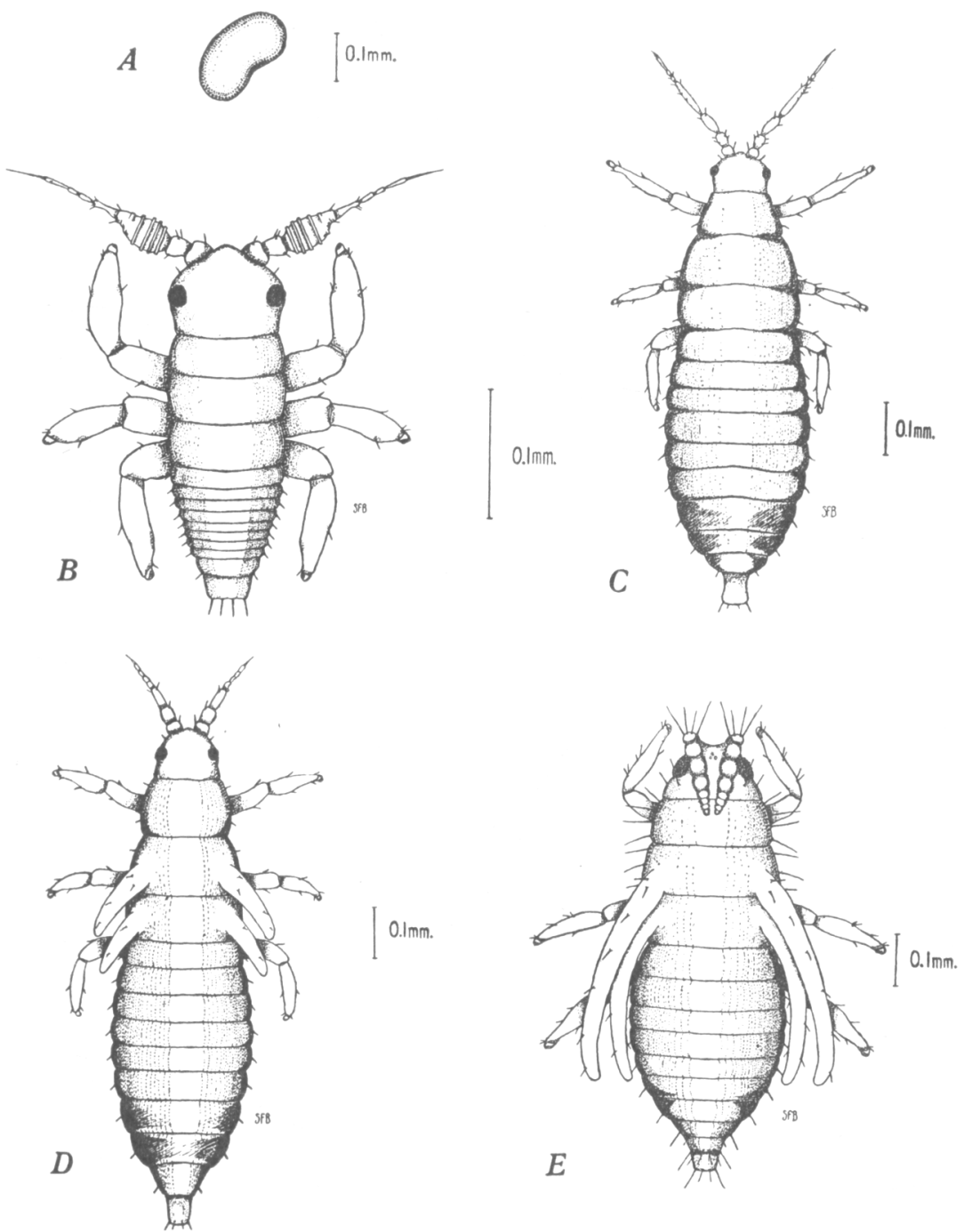

Fig. 1. The bean thrips. $A$, egg ; $B$, newly emerged larva; $C$, mature larva; $D$, prepupa ; $E$, pupa.

Egg.-Very delicate with thin chorion, bean-shaped (fig. 1, $A$ ), translucent white in color, and smooth; average width or diameter, $0.112 \mathrm{~mm}$; average length, 0.225 $\mathrm{mm}$. With the development of the embryo the egg swells and often the outlines of the larva may be seen, especially the eye-spots.

Newly Emerged Larva.-General shape somewhat fusiform; color, translucent white; head, antennae, and legs very large in proportion to body (fig. 1, $B$ ) ; average total length, $0.287 \mathrm{~mm}$. Antenna 8-segmented with long style, approximate length, $0.161 \mathrm{~mm}$; third segment very large with rather distinct rings. Eyes blackish red; 
ocelli wanting. Setae present, sparse on legs, antennae, and sides of abdomen; longest on posterior abdominal segment. Abdomen tapering, tenth segment very large in proportion and usually upturned.

Mature or Second-Stage Larva.-Shape fusiform; reddish yellow in color with variable crimson blotches and bands along sides of thorax and abdomen (fig. 1, C) ; antennae, legs, and posterior abdominal segment, pale yellow. Setae sparsely scattered on legs, antennae, and margins of thorax and abdomen, becoming larger at sides and on tenth abdominal segment. Average total length, $0.960 \mathrm{~mm}$. Antennae 8-segmented and about $0.256 \mathrm{~mm}$ in length. Eyes small, reddish orange; ocelli wanting. Abdomen fusiform, crimson bands usually extending across segments seven, eight, and nine, but considerable variation present in individuals; posterior segment tubular, usually curving upwards.

Prepupa.-Shape similar to that of mature larva; color, orange with variable crimson markings at thorax and abdomen, bands of erimson usually extending across seventh and eighth abdominal segments; legs and antennae, translucent white; setae occur sparsely on antennae, legs, and at sides of thorax and abdomen, tenth abdominal segment having ring of setae on posterior margin. Average total length, $1.008 \mathrm{~mm}$. Eyes dark orange with a few facets visible; ocelli wanting. Antenna 8-segmented, length approximately $0.175 \mathrm{~mm}$; segments difficult to distinguish and with much less shape than in larva. Wing pads very short (fig. $1, D$ ), translucent white, with a few scattered setae, fore wing pad extending to first abdominal segment, hind wing pad extending to second abdominal segment. Abdomen fusiform. Sexes extremely difficult to distinguish, females usually somewhat larger and more plump.

Pupa.-The pupal stage might well be divided into the early and late stages. In the early stage the general color is orange and the red markings on the sides of the abdomen are smaller and less distinct. The entire body appears much shorter and stouter than the prepupa. Average total length, $0.864 \mathrm{~mm}$; antennae rather shapeless and folded back over head (fig. 1, $E$ ), usually bending between first and second segments; segments indistinct and second segment with four long setae projecting forward; length of antennae about $0.162 \mathrm{~mm}$. Eyes much larger and darker red in color than in prepupa; three orange-colored ocelli are plainly visible between eyes in a triangle. Wing pads, like antennae and legs, translucent white: wing pads have scattered setae present on surface and extend to sixth or seventh abdominal segment. Abdomen fusiform in shape with irregularly distributed crimson markings at sides. Setae present along sides of thorax and abdomen, ninth and tenth abdominal segments having long setae on posterior margins. Ovipositor rather clearly demarked in female so that sexes can be readily distinguished.

In the late pupal stage the antennae come forward slowly, straighten out, and begin to darken up noticeably. The abdomen also begins to exhibit considerable pigmentation, particularly along the sides, nearly blotting out the red markings. The wings within their cases next darken and the cross-bands can be distinctly seen. Next in order the legs darken slightly, followed by the head and thorax and the reticulation can be seen on the surface of the body. Molting and the emergence of the adult occurs at about this point.

Adult Female.-General shape fusiform; average total length, $1.136 \mathrm{~mm}$; uniform dark brown in color; reticulation faint on head, prothorax, and at sides of meta- 

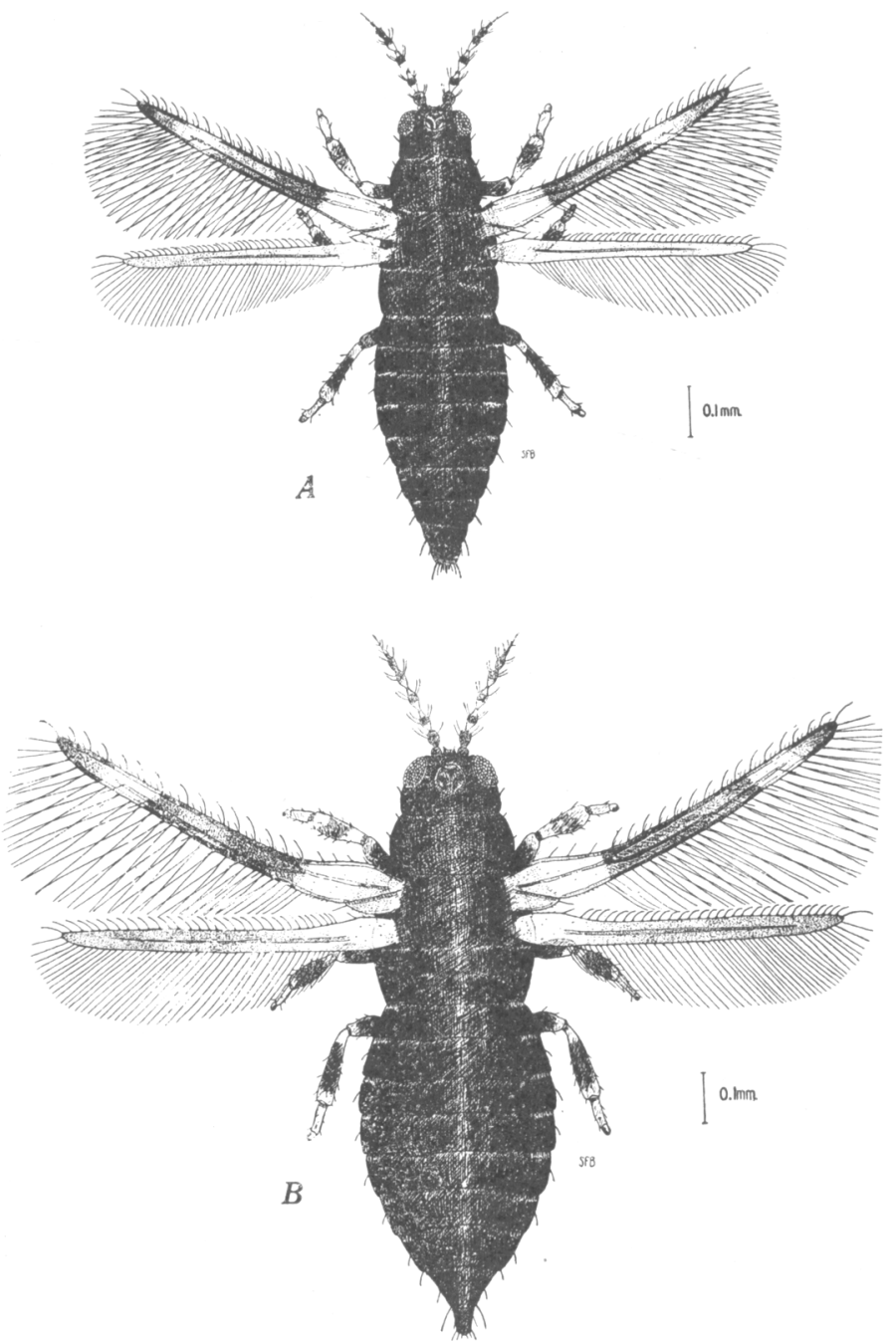

Fig. 2. The bean thrips. $A$, adult male; $B$, adult female.

thorax and abdomen. Head extends forward between antennae in a $U$-shaped process to about half the length of first antennal segment. Eyes small, black, with facets distinct; ocelli three, in a slightly elevated area between eyes, pale yellowish margined with dark orange. Antennae about $0.265 \mathrm{~mm}$ in length, 8-segmented; first and second segments uniform brown, third and fourth with middle third brown and remainder of segments pale yellow; anterior half of fifth segment brown and remainder of segments uniform brown.

Both pairs of wings appear to be joined to the mesothorax (fig. 2, B), but the muscular attachments of the hind pair are in the metathorax. Average length of fore 
wing, $0.784 \mathrm{~mm}$; average length of hind wing, $0.740 \mathrm{~mm}$; fore wing with one branched vein in the center of wing dividing at inner edge of dark band. Anterior branch becomes contiguous with costal vein and posterior branch continues distinct to center of white area near tip. Costal spines usually 20 ; number of spines on posterior fork of midvein variable, 5 to 7 ; number of hairs in fringe on hind margin of wing variable, usually 30 . Fore wing grayish brown, darkest along veins; dark area in center of wing equal to about one-half of wing's length, basal fourth white, and distal fourth equally divided into light and dark areas, tip dark. Hind wing uniformly grayish brown, basal fourth light; one longitudinal vein in center of wing becoming indistinct near base and not reaching tip; spines on costal margin about 32 in number; number of hairs in fringe variable, usually 42 ; entire surface of wings covered with very fine hairs.

Femora dark brown except at tips; tibiae with central portion dark brown, extremities yellow; fore tibiae somewhat lighter brown; setae distributed irregularly on tibiae and tarsi; hind femora only with setae; spines present also on lateral margins of head, prothorax, and abdomen; ninth and tenth segments of abdomen with a row of long spines on posterior margins. Short, strong spines are present on posterior-lateral margins of abdominal segments. Abdomen slightly broader than thorax, ovate, tapering sharply to last segment. Ovipositor visible under magnification, extending up into eighth segment. Approximate length of ovipositor, $0.167 \mathrm{~mm}$.

Adult Male.-The male differs but slightly from the female; it is somewhat smaller in size, the abdomen tapers more gradually, and the terminal abdominal segment is more blunt (fig. $2, A$ ). The coloration, markings, and setae are practically identical. Under magnification the reddish-orange testes may be seen suspended in the seventh and eighth abdominal segments. The external portions of the genetalia may be seen to extend slightly beyond the end of the abdomen.

There is another character that readily separates the sexes, as is the case in most of the Terebrantia, i. e., on the ventral surface of the abdominal segments of the male there are transverse elliptical areas, more or less transparent and pale yellow in color. In certain species there are six of these elliptical areas, on the second to the seventh segments inclusive. However, in Hercothrips fasciatus there are only five of these areas present on the second to the sixth segments; the female does not have these elliptical areas.

Average total length, $0.864 \mathrm{~mm}$; length of antennae about $0.224 \mathrm{~mm}$. Width of elliptical areas on under side of abdominal segments $0.016 \mathrm{~mm}$, and length, $0.032 \mathrm{~mm}$.

Color Variation.-The newly emerged adult differs considerably in coloration from the fully matured individual. This differentiation led Reuter (1891) to establish a variety abdominalis of Heliothrips haemorrhoidalis which Pomeyrol (1928) pointed out as merely the newly emerged adult of $H$. haemorrhoidalis which had not hardened and taken on its adult coloration. When just emerged, the thorax of Hercothrips fasciatus is of a dirty yellowish brown with a darker head. The red markings so characteristic of the larva and pupa can still be seen faintly at the sides of the abdomen. The antennae and legs are pale but have 
the dark-brown areas very distinct. The eyes and ocelli are a dark brownish red. The wing bands are clearly demarked. The black pigment appears to be first deposited at the sides of the abdomen, obliterating the red blotches, and spreads gradually over the remainder of the body.

Whenever larvae are forced to feed in the direct sunlight, they become very highly colored.

\section{ORIGIN AND DISTRIBUTION}

Very little work indeed has been done on the geographical distribution of the Thysanoptera as correlated with the life zones, and even less information is available on the geological distribution of the insects of this order. Doubtless the small size and rather delicate structure of the thrips has resulted in the paucity of specimens given us as fossils today.

In regard to the geographical distribution of the Thysanoptera on the basis of Merriam's life zones, Watson (1926) wrote that the Thysanoptera of North America practically ignore Merriam's zones and that the Thysanopteran fauna of Florida is more closely related to that of Massachusetts and Northern Europe than to that of California. The same author also stated that there was no evidence that the distribution of the Thysanoptera corresponds in the least to the formations or societies as set up and defined by ecologists.

As to the original home of the bean thrips, little can be stated in a definite way. Certain authors have suggested that it is indigenous to California, and collections and the observed habits of the insect show that it exists in this state on the native vegetation far from cultivated crops (Moulton, 1907). Watson (1923) reported this thrips on native vegetation in Florida and inferred that Hercothrips fasciatus might be indigenous to Florida. Also Bondar (1924) collected it in Bahia, Brazil, and suggested that it was indigenous in that country. There are scattered records in the literature of this species from the west coast of Mexico, Arizona, and Texas; also some unpublished data (kindly furnished by Dr. W. E. Hinds, Louisana State University, and by Professor Franklin Sherman of Clemson College, South Carolina) extend the known distribution of the bean thrips to Alabama, Louisana, and South Carolina. Steinweden and Moulton (1930) reported the collection of one female bean thrips from citrus at Foochow, China. Until there is further evidence, it can only be said that $H$. fasciatus is actually indigenous to the warmer climates. 
The known distribution of the bean thrips at this writing includes records from the following states: California, Nevada, Idaho, Arizona, Texas, Louisana, Alabama, Florida, and South Carolina. In addition to the United States we have one record from the west coast of Mexico, one from Bahia, Brazil, and one from China. Extensive and thorough collections of thrips in North America would no doubt establish many new records of the distribution of this species, particularly in such states as New Mexico, Mississippi, and Georgia.

Concerning the distribution of the bean thrips as regulated by altitude (in California) we can report its collection rather commonly up to 2,000 feet; and even up to 3,000 feet this species has been taken on Lactuca scariola.

The present known distribution of the bean thrips in California is shown in figure 3.

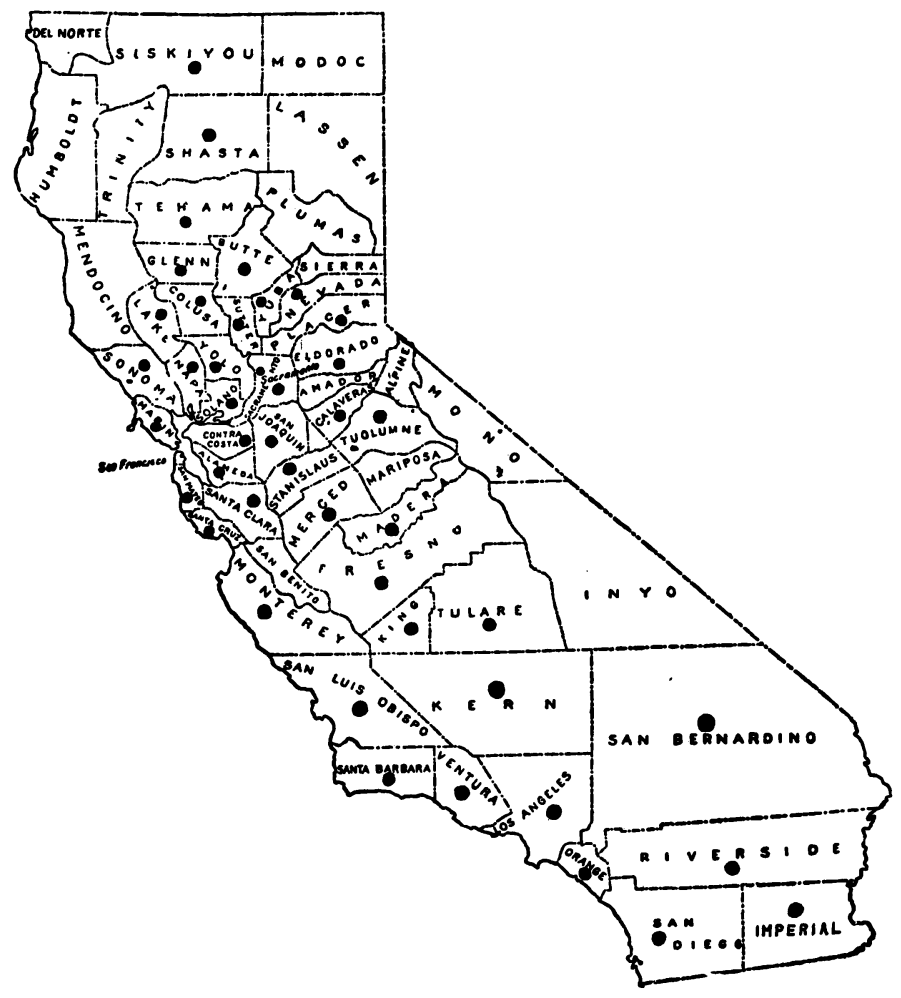

Fig. 3. Distribution of the bean thrips in California. 


\section{NATURE OF INJURY}

The injury done by the bean thrips is the direct result of the feeding of the larvae and adults upon plant tissue. In the feeding act the mouth cone is applied to the leaf surface and the initial incision made with the mandibles and their stylets which are protruded from the concave side of the labrum. The long maxillary stylets are then brought into play and used to puncture the deeper cell layers. A rooting motion of the head is employed to enlarge the opening and cause the plant juices to flow more rapidly. The labrum, which bears at the tip a round socket through which the stylets pass, is closely appressed over the lesion and the fluids sucked up. Peterson (1915) wrote concerning the sucking action "The muscles along the meson of the elastic membrane (of the pharynx) contract and dilate the lumen of the pharynx so that a partial vacuum is formed, and into this cavity is sucked the juice in which the tip of the mouth cone is immersed. On the relaxation of the dilating muscles, the elastic membrane forces the food dorsad through the open valve into the oesophagus."

Some authors have stated that the secretions of the salivary glands are toxic to the plant, but this has recently been discredited.

Wardle, Simpson, and MacGill (1927) stated that, in the case of the onion thrips, "The stylets can be protruded beyond the labial rim $11 \mu$ in the case of the mandible and $27 \mu$ for the stylets of the maxillae. Whether the hypopharynx can be protruded is uncertain."

As to the relative amount of injury done by the adults as compared with the larvae, there are no actual figures to present. However, from careful observations, both in the field and the laboratory, on the basis of the area eaten over and the amount of excrement deposited, it appears that the larvae do a great deal more feeding than do the adults. This is as would be expected as the larvae are present in much larger numbers; they are less active and confine their feeding to a limited area; they feed gregariously; and they have to store up sufficient food to carry them through the pupal stage with its demand for stored energy. The adult male does much less feeding than the female.

The actual damage resulting from oviposition in the leaves is very slight. When the egg is deposited, a very small lesion is made by the insertion of the sawlike ovipositor, which is not more than $0.167 \mathrm{~mm}$ long and $0.059 \mathrm{~mm}$ wide at the base. The scar left in the leaf tissue after the larva has hatched is approximately $0.25 \mathrm{~mm}$ long. 
The actual damage of the bean thrips is caused, almost entirely, in the case of the pear tree particularly, by the premature and excessive defoliation. This not only weakens the tree for the ensuing season but exposes both the new growth and the fruit to "sun-scalding" in the hottest part of the summer.

Wardle, Simpson, and MacGill (1927) have done some excellent work on the actual nature of injury of the onion thrips to the cotton plant. These authors stated that the lower side of the leaves is preferred on account of the difference in the epidermal thickness. The very old and very young leaves are free from thrips since the older leaves are too tough and the young leaves are put forth ahead of the infestation. They wrote further : "leaf injury consists essentially of necrosis of a patch of mesophyll cells lying immediately below a gash in an epidermal cell." The lesions are divided by these authors into four progressive stages: (1) Palisade layer intact, epidermis intact, and a slight disorganization of the outermost mesophyll layer and air spaces. (2) Mesophyll and lower epidermis become more disorganized. (3) Mesophyll nearly all gone and the palisade layer beginning to shrivel. (4) All tissues, including the upper epidermis, disorganized. This exact succession of stages of the lesions will doubtless vary under different conditions and in different plants.

The injury, as evidenced by the dropping of the pear leaves is first noticed, by the growers in the Berryessa Valley (Napa County) particularly, about the middle of July. The browning and curling of the leaves which are shed is apparently the result of the desiccating effect of the hot sun upon the leaves injured by thrips feeding. The older leavesthat is, the ones earliest infested, seem to drop first. The evidence that uninjured leaves in the direct sun, and badly injured leaves that are well shaded, do not turn brown and drop, seems to substantiate the foregoing conclusion.

As a result of the dying and dropping of large numbers of leaves and the toughness of the older remaining leaves, the thrips are driven to the pear fruit. The author has observed many terminals, entirely naked of leaves, with a single pear hanging from it infested with upwards of 100 thrips larvae. The injury to the fruit is in the nature of ugly scars and minute oily drops of excrement which lower the grade and marketability to a serious degree. Such injury occurs only in very heavily infested local areas where early defoliation is present. Of a total of 5,265 pear fruits counted August 6, 1930, on the Eccleston ranch, Berryessa Valley, at the height of the infestation, 781 showed damage, giving about 15 per cent injury. 


\section{HOST PLANTS}

A true host plant is taken to be one on which the egg, larval, and adult stages are found (the pupal stage being passed in the soil). It is impossible to ascertain whether the hosts recorded from various sources are, in this respect, true hosts or not, or whether the adults were there transitorily, or hibernating. In general, the bean thrips is not found on plants that are heavily pubescent; tender succulent plants seem to be preferred as is evidenced by the infestations on the young growth.

It is very doubtful if the bean thrips can survive on pines. Adults were confined on Pinus radiata at Davis, and none lived more than three days. The adults reported as taken on pine were probably hibernating.

A large list of host plants is given by Russell (1912b), Essig (1915, 1926), and Watson (1923), and the plants listed by them and others are included here with new and additional hosts :

\section{Crop Plants}

$\begin{array}{lll}\text { Alfalfa } & \text { Cotton } & \text { Peas (garden and } \\ \text { Almond } & \text { Grape } & \text { cowpeas) } \\ \text { Apple } & \text { Kale } & \text { Persimmon } \\ \text { Avocado } & \text { Lettuce } & \text { Potato } \\ \text { Beans } & \text { Olive } & \text { Prune } \\ \text { Beets } & \text { Onions } & \text { Radishes } \\ \text { Cabbage } & \text { Orange } & \text { Swiss chard } \\ \text { Cauliflower } & \text { Peach } & \text { Tangerine } \\ \text { Clover, red } & \text { Pear } & \text { Tomatoes } \\ \text { Corn (young shoots) } & & \text { Turnips }\end{array}$

\section{Wild and Ornamental Plants}

$\begin{array}{ll}\text { Amaranthus retroflexus (rough } & \text { Convolvulus arvensis (morning-glory) } \\ \text { pigweed) } & \text { Crepis } \text { sp. (hawksbeard) } \\ \text { Anthemis cotula (mayweed) } & \text { Echinocystis } \text { sp. } \\ \text { Arundinaria japonica (bamboo) } & \text { Erigeron canadensis (horseweed) } \\ \text { Asclepias mexicana (milkweed) } & \text { Erodium cicutarium (red-stem filaree) } \\ \text { Aster } \text { sp. } & \text { Eschscholtzia californica (California } \\ \text { Atriplex } \text { sp. (saltbush) } & \text { poppy) } \\ \text { Bidens pilosa (bur marigold) } & \text { Foeniculum sp. (fennel) } \\ \text { Brassica campestris (common yellow } & \text { Geranium sp. (cranesbill) } \\ \text { mustard) } & \text { Gnaphalium decurrens } \text { var. californicum } \\ \text { Canna } \text { sp. } & \text { (California everlasting) } \\ \text { Cassia } \text { sp. } & \text { Helianthus annuus (common sunflower) } \\ \text { Chenopodium murale (nettle-leaf } & \text { Heliotropium currassavicum (Chinese } \\ \text { goosefoot) } & \text { pusley) } \\ \text { Cirsium edule (Indian thistle) } & \text { Hemizonia } \text { sp. (tarweed) }\end{array}$


Iris germanica

Lactuca scariola (prickly lettuce)

Lactuca scariola var. integrata

Lotus americanus (Spanish clover)

Lotus scoparius (deerweed)

Lupinus sp.

Malva parviflora (mallow)

Medicago hispida (bur clover)

Melilotus alba (white melilot)

Mentha sp. (mint)

Mentzelia laevicaulis (blazing star)

Mirabilis laevis (wishbone bush)
Monita perfoliata (miner's lettuce)

Nicotiana glauca (tree tobacco)

Polygonum aviculare (wire grass)

Pueraria hirsuta (Kudzu)

Pyracantha sp. (firethorn)

Sonchus oleraceus (common sow-thistle)

Stellaria media (common chickweed)

Tacsonia mollissima (passion flower)

Tropaeolum majus (nasturtium)

Tulipa sp.

Verbascum virgatum (mullein)

Vicia $s p$. (wild vetch)

\section{LIFE HISTORY}

Rearing Methods and Technique.-Both larvae and adults were collected by sucking them into a minature wash-bottle apparatus (Bailey, 1932). Plain cellophane (No. 300 permeable) envelopes were used in caging the thrips on host plants. These envelopes were placed over single leaves or entire terminals, cotton was wrapped around the petiole

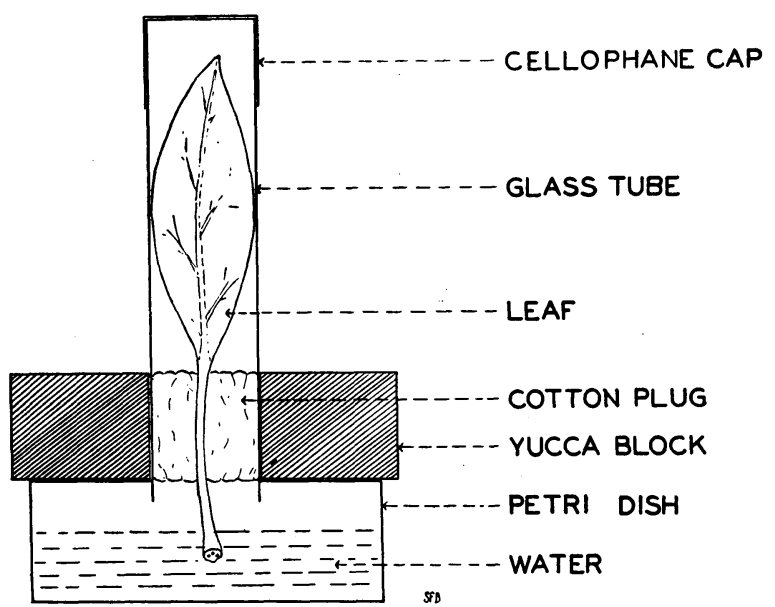

Fig. 4. Type of cage used in rearing thrips in the laboratory.

or twig, and the cage constricted and tied tightly at this point with string. In addition to using potted plants with cellophane eages in the laboratory, a series of glass tubes $1 / 2$ to $3 / 4$ inch in diameter and 3 inches long were employed as rearing cages (fig. 4). Since the grade of cellophane used is permeable to atmospheric conditions (Bailey, 1931), considerably less condensation of moisture resulted from transpiration and the danger of the thrips' drowning was reduced. This method facilitated 
observations, the changing of food, and keeping a supply of water present without allowing the thrips to escape. A camel's-hair brush was used in transferring the small larvae.

The most satisfactory food was found to be pear and bean leaves. Sprigs of alfalfa, while being very satisfactory from many standpoints, prevented accurate counts and observations since the leaves and blossoms were too dense and overlapping.

A specially constructed air-conditioning cabinet was employed in studying the effect of temperature and humidity upon various stages in the life history. Cold chambers, in which the humidity was uncontrolled, were used in obtaining constant temperatures below $50^{\circ} \mathrm{F}$.

Further details on the technique used in these studies are given with the experiments which are reported in following pages.

Hibernation.-The bean thrips hibernates in the adult stage. Local conditions' regulate the place of hibernation as well as the duration of the dormant period. Hibernation seems to be chiefly a temperature reaction since inactivity on the part of the adults can be brought about under controlled conditions by lowering the temperature, and normal activity is resumed upon subsequently raising the temperature. Both the entrance into and the emergence from hibernation is gradual and, even on exceptionally warm days (maximum temperature $75^{\circ}-80^{\circ} \mathrm{F}$ ) in the winter, they exhibit some activity.

Only a very slight amount of feeding seems to be done during hibernation and practically no excrement is to be seen on the leaves of the plants furnishing the protective quarters. All activity is at a minimum, and they are found nearly always clustered together and will, if disturbed, move about very slowly. The abdomen of the hibernating adults appears shrunken and flat and the wings in many cases seem to be stuck together. When dormant adults were taken into the laboratory and warmed up, the males seemed to react first, the females being much more sluggish. When sufficiently warmed up, they began to hop about and commence feeding. Temperatures as low as $16^{\circ} \mathrm{F}$ appeared to have little effect on the hibernating adults in the field.

About the last of October or the first of November, the adults become inactive and seek out hibernating quarters, migrating chiefly to plants that are still green. Egg laying, copulation, and finally feeding cease and the adults begin to cluster in protected places. The overwintering population appears to suffer a heavy mortality, and many individuals have been found dead in drops of water standing on the leaves, and large numbers of dead have been observed stuck to wet leaf surfaces. Only those adults extremely well protected seem to survive the drench- 
ing rains of the winter season. By the last of March the survivors become active and gradually migrate to alfalfa and various weeds, such as prickly lettuce, sow-thistle, and filaree, occurring nearby.

This insect then passes about five months of the year in hibernation, i. e., from the latter part of October or the first of November to the last of March or the first of April.

At Davis in the fall of 1929, adult bean thrips were found hibernating at the base and in the angles of onion stalks in an isolated seedbed, and on the under side along the midrib of Swiss chard leaves, particularly those close to the ground. In January, February, and March, 1930, adults were found hibernating at the base of iris leaves, and here again on those leaves close to the ground.

Mr. F. H. Wymore collected hibernating adult bean thrips on orange leaves infested with soft brown scale (Coccus hesperidum L.) at Davis, December 16, 1929. The thrips were huddled among the scales and some were even in the emergence holes of the parasitized scales.

In Monticello (Napa County) in October, November, and December, 1929, adults were found on red-stem filaree in the pear orchards. During the winter it is very difficult to find the remaining scattered adults on account of the profuse growth of weeds and their wet, matted condition.

In the winter of 1930-31 a more extensive search for hibernating adult bean thrips resulted in finding large numbers hibernating on various ornamentals at Davis. In addition to iris, adults were collected from the under side of the leaves of roses, Pyracantha, Viburnum, and Canna.

L. A. Whitney (1930) reported that, during inspection work in Hawaii in December, 1929, hibernating adults of Hercothrips fasciatus were found on shipments of persimmons, tangerines, and oranges from California. Russell (1912b) reported that Professor Lawrence Bruner took hibernating adult bean thrips from the navel end of oranges at Lincoln, Nebraska, February 14, 1899, and at Urbana, Illinois, March, 1907. In both instances the oranges were from California.

Activities of the Newly Emerged Adult.-It has been noticed in the laboratory, from a very large number of pupae collected in the field as mature larvae, that newly emerged adults are inactive for about 24 hours. When a number of mature larvae pupate on the same day, the females, in every case observed, emerge as adults 10-30 hours before the males. Mating has never been observed on the part of newly emerged adults without first having fed. They remain quiet for the first day, probably for the hardening up of the exoskeleton and full deposition of 
pigment. An occasional individual will live as long as six days after emerging without food or water.

Feeding begins in earnest on the second day, and is increased on the third day. Copulation has been observed on the second day in a few instances and oviposition has been found to occur as early as the third day after emergence. These activities seem to vary, however, with the temperature. Oviposition has been observed in a number of cases on the fourth day after emerging on the part of unfertilized females.

Ability of the Adult to Burrow Up Out of the Soil.-The adult bean thrips do not have much ability to force their way up through the soil. It was thought that the newly emerged adults crawl to the surface through cracks and openings in the soil rather than actually forcing their way through the compact soil. If the structure and position of the soil particles are altered after the mature larvae have found a suitable place in which to pupate, it was shown that the adults cannot make their way to the surface, and consequently die.

Mature larvae and pupae were placed in pint jars and coarse or fine sand from $1 / 2$ to 3 inches in depth carefully spread over them. Over the mouth of each jar was stretched white cotton cloth held tightly in place by a rubber band. The jars were set on a laboratory table and inspected daily for newly emerged adults by examining the under side of the cloths, care being taken not to disturb the soil. Jars Nos. 1 and 2 contained pupae that had darkened up and were about ready to emerge. Jars 3, 4, and 5 contained prepupae and pupae, and jars 6, 7, and 8, mature larvae only. A summary of the experiments is given in the accompanying tabluation.

\begin{tabular}{c|c|l}
\hline Jar & $\begin{array}{c}\text { Number of } \\
\text { forms }\end{array}$ & \multicolumn{1}{|c}{$\begin{array}{c}\text { Kind and depth of } \\
\text { covering }\end{array}$} \\
\hline 1 & 10 & 1/2 inch fine soil \\
2 & 12 & 1/2 inch coarse soil \\
3 & 10 & 1 inch fine soil \\
4 & 20 & 1 inch coarse soil \\
5 & 10 & 3 inches coarse soil \\
6 & 35 & 1 inch fine soil \\
7 & 12 & 1 inch coarse soil \\
8 & 32 & 3 inches coarse soil \\
\hline
\end{tabular}

Normally the adults should have appeared in one day from jars 1 and 2 and in about six days from jars 6, 7, and 8. However, after ten days no adults had appeared and we were forced to assume that they could not burrow to the surface when covered in this manner. 
Feeding Habits of the Adult.-A description of the mechanies of the feeding process has been included under the section on "Nature of Injury." The adults are found feeding together with the larvae but do not feed as gregariously or as consistently in a given area as do the larvae. The mature forms are very seldom found on the older and more heavily infested leaves but have moved on to the younger leaves above and are to be found there feeding and ovipositing. As is the case with the larvae, the adults seem to prefer the under side of the leaf, which is more tender.

It is interesting to note that even though the adult bean thrips are found feeding in company with the larvae, the majority of them are to be found above the congregations of larvae and on the newer and cleaner leaves where copulation and oviposition take place. This advance into new territory can be easily observed on lettuce plants, particularly isolated ones, but is more difficult to follow on pear trees on account of the dense foliage and the spreading habit of the tree. However, as the season progresses it can be noted that the lower branches are infested first and by the middle of the summer the entire lower half of the pear trees will show severe injury while the tops of the trees usually are free from the thrips.

Method of Reproduction.-The subject of reproduction in the Thysanoptera offers an extremely interesting study because of the variation in the type of reproduction even among closely related species. The suborder Terebrantia includes the large majority of the species that are of economic importance and, therefore, much more is known of the biology of the species in this group, while very little indeed is known of the other suborder, the Tubulifera. There is too little known of the method of reproduction among the species of the Thysanoptera to state whether the normal form is bisexual, parthenogenetic, or even facultative. In addition, even less is known concerning the seasonal variation in the method of reproduction which apparently occurs in some species and the effect of climatic conditions on this phenomenon.

The unusual condition pertaining to reproduction in this order of insects was realized by the early workers. Jordan (1888) considered that there might be an alternating life cycle in the order, but Uzel (1895) held that parthenogenesis was not facultative and that a female was either only sexual or only parthenogenetic.

Two of the best known species of the Terebrantia, the greenhouse thrips, Heliothrips haemorrhoidalis Bouché, and the pear thrips, Taeniothrips inconsequens Uzel, reproduce entirely by parthenogenesis and the males are not known (Buffa, 1911, and Foster and Jones, 1915). 
On the other hand, the bean thrips, Hercothrips fasciatus, and the sugar beet thrips, $H$. femoralis Reuter, are thought to reproduce bisexually under normal conditions (White, 1916). There also seems to be an intermediate stage as in the case of the redbanded thrips, Selenothrips (Heliothrips) rubrocinctus (Giard), concerning which Russell $(1912 c)$ wrote "Reproduction for portions of the year is parthenogenetic, but at other times bisexual." Also, Shull (1914a) reported some very interesting observations and experiments on the method of reproduction of several species. Of Frankliniella tritici Fitch, he (Shull) wrote that only the females survive the winter and that the males occur late in autumn and "if fertilization of the early spring females takes place at all, it must occur in the fall." He stated further that the male of the onion thrips (Thrips tabaci Lind.) occurs but rarely and that "their appearance in late summer may be the vestige of a former sexual phase, and may be caused now, as the sexual phase probably was in part formerly caused, by climatic conditions."

Additional references further bring out the condition which evidently prevails also in the Tubulifera. Shull (1914b, and 1915) found Haplothrips leucanthemi (Schrank) = Anthothrips niger (Osb.) to reproduce parthenogenetically and no males were known to occur, and he also found Neoheegeria (Anthothrips) verbasci (Osb.) to be parthenogenetic in addition to reproducing bisexually. He wrote, "The discovery of parthenogenesis in such a species greatly reduces the probability that sexual reproduction is of common occurrence in the Thysanoptera as a group." In 1917 Shull reported some further studies with this species and wrote "There is abundant proof of these experiments that unfertilized eggs produce males" and "when males are present, females appear among the offspring." Yothers (1924) wrote that the "Reproduction of the camphor thrips (Cryptothrips laureli Mason) seems to be almost entirely by parthenogenesis. No males have ever appeared in the breeding jars at any time of the year. Occurring in nature rather rarely, it is doubtful if the males fulfill any necessary rôle in the propagation of the species."

Some of the recent workers have brought out even more clearly the point that there appears to be an alternation in the method of reproduction in certain of the Thysanoptera. Raymond (1924) stated that there is a regular alternation of parthenogenesis and sexual generations in Physopus pallipennis; i.e., sexual in the summer and parthenogenetic at the end of the summer and in the spring (after hibernation). Radulesco (1930) made the very interesting observation that in Parthenothrips dracaenae Heeg. there are two races present, one partheno- 
genetic and the other sexual, which develop simultaneously and under the same conditions in the region of Paris. This author also reported on Aptinothrips connaticornis Uzel and stated that it is a variety of $A$. rufus Gmel. which gives rise to the variety under certain conditions of temperature and dryness. A. connaticornis was reared throughout the year from isolated unfertilized females and Radulesco concluded that perhaps there is a sexual race that has given rise to a parthenogenetic one and is itself in the course of dying out. Davidson and Bald (1930 and 1931) while studying the bionomies of Frankliniella insularis (Franklin) found that while males were normally present, isolated unmated females reproduced parthenogenetically. Another recent paper, Eddy and Livingstone (1931), reports a rather exhaustive study of the reproduction and inheritance of sex in Frankliniella fusca Hinds. They found, as did Shull (1917), that "The unmated females produced always male progeny .... the males do not survive the winter, and that males produced parthenogenetically in the spring mate with the overwintered females to produce females."

There must be a great many species of Thysanoptera that reproduce by parthenogenesis for Priesner (1926) listed 26 species of European thrips in each of which the male was unknown.

Whether reproduction is parthenogenetic or bisexual, in every case cited above and in many others, the reproduction of the species is oviparous. However, we have one isolated case (John, 1923) of viviparity in the Thysanoptera. This author published an account of the life history of Megathrips lativentris Heeg. which he worked out at Petrograd. The males of the species are reported as rare, but copulation and bisexual reproduction have been observed. The eggs hatch the moment they are laid and the dissection of females revealed embryos within the egg shell in the egg tubes. Embryos in different stages of development were found and one free larva was discovered within a female thrips. A total of as many as 20 eggs were dissected out of the eight eggs tubes of one female and the author further stated that the egg can develop in the ovarian tube without coming in contact with the sperm since the seminal receptacle does not open into the tube. No attempt was made by the author to explain this phenomenon of facultative viviparity and its phylogenetic relation to the rest of the order.

The bean thrips, like Frankliniella tritici and Neoheegeria verbasci, normally reproduces bisexually and males are found present through the entire year, but the females are able to reproduce parthenogenetically. Unfertilized females always produce males. Copulation is normal and necessary to produce the preponderance of females found in nature. 
Very little information is available on the method of reproduction in the genus Hercothrips. Russell (1912) wrote: "In all observations on this topic reproduction has been bisexual, and in view of the fact that males were observed at all times and copulation also occurred at all times in the year when they were active, this would seem to be the usual method. However, although the few experiments made to determine whether parthenogenesis occurred gave negative results, in view of the preponderance of females during certain parts of the season, it is quite probable that asexual reproduction may occur. It would seem that this method would occur under certain conditions, especially in view of the fact that the greenhouse thrips, Heliothrips haemorrhoidalis, reproduces, so far as we know, asexually only, the male having never been discovered." White (1916) wrote concerning reproduction in Hercothrips (Heliothrips) femoralis Reuter-"The normal mode of reproduction is bisexual, but owing to the fact that at certain intervals the proportion of males to females is very small, it is likely that parthenogenesis occurs as in other species of this group."

Russell was correct in his suggestion that "asexual reproduction may occur" in the bean thrips but it is of a different type from that which occurs in Heliothrips haemorrhoidalis. In the latter the male is not known and the parthenogenetic females give rise to successive generations of parthenogenetic females (Buffa reared the greenhouse thrips for 23 months and no males appeared), but in the bean thrips the males are necessary for the production of females and the preservation of the species. It follows then, as Eddy and Livingstone (1931) pointed out in Frankliniella fusca, that, if the males of $\boldsymbol{H}$. fasciatus do not survive the winter, the females produce males parthenogenetically. These males, composing the first generation, mate with the surviving females to produce females (second generation of the season). The study made of hibernation of the bean thrips, however, showed that males do winter over under normal conditions.

Further studies by the author show that in the case of the bean thrips, as Shull (1917) indicated in the case of Neoheegeria verbasci, repeated mating is necessary to produce the normal sex ratio occurring in nature. Shull wrote that this condition "is explained on the assumption that the spermatozoa were all allowed to fertilize the eggs at first, and that subsequent eggs were unfertilized" which seems to be the only logical explanation.

Several authors have suggested that climatic conditions play a part or even govern the method of reproduction in the Thysanoptera. Observations, counts, and experiments have not shown this to be the case 
in Hercothrips fasciatus. In the laboratory under controlled conditions, in the greenhouse, and in the field the bean thrips has been found to reproduce bisexually and, when no males are present, the unfertilized females produce only male progeny.

In these experiments the females were obtained by collecting mature larvae in the field or by raising them in the laboratory, allowing them to pupate, and isolating the female pupae as soon as they had developed sufficiently to enable the sexes to be distinguished. These virgin females upon emerging were placed on uninfected leaves of beans or pear. Their progeny were raised to maturity and the sex determined. Cellophane envelopes were used in the field and glass tubes were employed in the laboratory (see section "Rearing Methods and Technique"). The females were changed to fresh leaves every five or eight days with the collecting apparatus or a camel's-hair brush. Individuals classified as "mated" were observed to copulate in vials before being isolated. The mature larvae were allowed to pupate on the cotton plugs both in the field cages and in the glass tubes in the laboratory. Check cages of mated individuals were run in each experiment when the potential parthenogenesis of virgin females was being tested.

During the summers of 1930 and 1931 a total of 22 experiments were conducted with unmated females to determine whether or not they were able to reproduce parthenogenetically. In these experiments a total of 274 unfertilized females were used, all of which gave positive results and the progeny which were reared to maturity from 140 individuals were all males. In the check cages in the field where males were continually present and promiscuous mating took place, the proportion of sexes was 35 per cent males and 65 per cent females, which is only a slightly higher percentage of males than found in the field collections of adults.

A number of females reared in the laboratory were mated once only in vials and then isolated on pear leaves to determine the proportion of sexes in the offspring. The experiment was continued in each case until the death of the female. The larvae hatching out in ten-day intervals were isolated and the sex determined when maturity was reached.

Table 1 gives a summary of this experiment. 
TABLE 1

Progeny of Females Mated Once Showing Proportion of Sexes

\begin{tabular}{|c|c|c|}
\hline \multirow{2}{*}{ Female No. } & \multicolumn{2}{|c|}{$\begin{array}{l}\text { Sex of progeny in suc- } \\
\text { cessive 10-day periods }\end{array}$} \\
\hline & Females & Males \\
\hline \multirow{5}{*}{1 (Length of life, 52 days)... } & 3 & 1 \\
\hline & 7 & 0 \\
\hline & 6 & 3 \\
\hline & 0 & 3 \\
\hline & 0 & 7 \\
\hline \multirow[t]{2}{*}{2 (Length of life, 22 days)...... } & 12 & 0 \\
\hline & 0 & 12 \\
\hline \multirow{2}{*}{3 (Length of life, 20 days)...... } & 6 & 0 \\
\hline & 0 & 5 \\
\hline
\end{tabular}

Females which are mated only once apparently either use up the sperm in fertilizing the eggs laid first or the remaining sperm becomes impotent and the eggs laid later are unfertilized.

Another set of experiments was conducted illustrating the converse of the above. Newly emerged unmated females were isolated on pear leaves for a given number of days; the larvae hatching out were carefully reared, and the sex of the adults determined. The original unmated females were then mated and again isolated and the sex of the offspring determined. A summary of this set of experiments is given in table 2.

TABLE 2

Proportion of Sexes in Progeny of Females, Before and After Mating

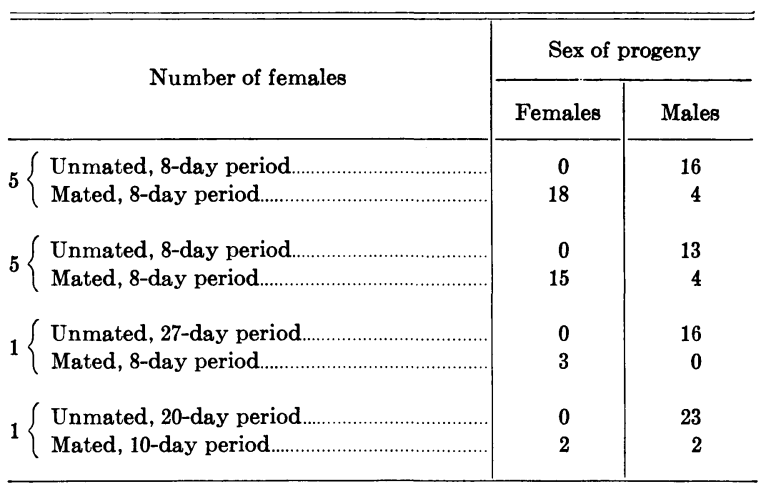


The unmated females produced only males and when mated produced nearly all females, the males appearing after mating probably came from eggs which in some manner escaped fertilization.

So, it can be seen that the bean thrips, while normally reproducing bisexually, is capable also of reproducing parthenogenetically. The males are then necessary to the continuation of the species and there is no evidence that a transition is taking place from a bisexual mode to one of parthenogenesis. Doubtless, in nature, females often reproduce parthenogenetically but the progeny in such an event, being all males would insure fertilization of any females remaining and the subsequent production of more females.

Copulation.-Copulation in Hercothrips fasciatus takes place as has been observed and described in other species by many workers in the suborder Terebrantia. The male being smaller and much more active than the female, when conditions are such as to stimulate copulation, avidly seeks out the female. The male either crawls or hops on to the back of the female and, as Russell (1912b) writes, "It then exerts the copulatory organs from the tip of the abdomen and shifts around toward the side of the female, at the same time bending the abdomen under the ventral side of that of the female. The copulating organs are then moved back and forth until they encounter those of the female." The length of time of connection varies from 2 to 10 minutes. At high temperatures $\left(95^{\circ}-115^{\circ} \mathrm{F}\right)$ the complete act is greatly shortened.

Egg Laying.-Both temperature and light seem to play important rôles in stimulating or retarding egg laying. Oviposition by the bean thrips is most frequently observed in the early morning and late afternoon. The process of egg laying has been observed to take place on both the upper and lower sides of pear, prune, and prickly-lettuce leaves. The duration of the act seems to vary greatly, depending on the condition of the leaf tissue, being from 4 to 9 minutes.

The act of oviposition begins, after the female has found a suitable place, by arching up the abdomen and extruding the ovipositor at right angles to the body. With a sawing motion the ovipositor is driven its entire length into the leaf and worked forwards and backwards to enlarge the slit. The female then rests before beginning the actual laying of the egg. Contractions and undulatory movements of the abdomen are visible and a firmer grasp of the leaf is taken by the feet. The female appears to labor heavily at the time that the egg passes out of the body and a slight exudation of excrement is sometimes visible. Often, after the ovipositor is withdrawn, a drop of excrement is placed over the slit made in the leaf. Feeding begins soon after the act is completed. 
The ovipositor is often caught or wedged in the leaf tissue and the female dies struggling to withdraw it. This seems to be more common on the older leaves. Many attempts at oviposition are made which are unsuccessful, owing, no doubt, to the toughness of the epidermis.

Proportion of Sexes.-The proportion of sexes throughout the year does not vary greatly. During the past two years collections and counts have been made to determine the exact relation in numbers between the sexes and the seasonal variation in the proportion if there be any. Collections were made in the field on various hosts throughout the year and counts were also kept of the sex ratio of adults reared in the laboratory. In all, 2,601 adults were counted, of which 1,769 were females and 832 males, which gives a ratio of 68.1 per cent females and 31.9 per cent males.

The proportion of sexes of 485 adults reared in the laboratory was found to be 72.5 per cent females and 27.5 per cent males. The proportion of sexes in greenhouses on beans was found to be 74.4 per cent females and 25.6 per cent males.

Collections of adults were made at Davis throughout the year and sex ratios recorded to determine whether or not there was any seasonal variation in the proportion of sexes in the bean thrips as is known to occur in many other insects. Table 3 gives a summary of the monthly collections and determinations.

TABLE 3

Seasonal Variation in Proportion of Sexes

\begin{tabular}{|c|c|c|c|c|c|c|}
\hline \multirow{2}{*}{ Date } & \multirow{2}{*}{ Host } & \multirow{2}{*}{ Females } & \multirow{2}{*}{ Males } & \multirow{2}{*}{ Total } & \multicolumn{2}{|c|}{ Sex ratio, per cent } \\
\hline & & & & & Females & Males \\
\hline July 19,1930 & Beans..... & 116 & 40 & 156 & 74.3 & 25.6 \\
\hline Aug. $\quad 4,1930$ & Prickly lettuce... & 70 & 33 & 103 & 67.9 & 32.0 \\
\hline Sept. 20,1930 & Canna, iris, and prickly lettuce... & 107 & 64 & 171 & 52.5 & 37.4 \\
\hline Oct. 18,1930 & Canna, iris, and ornamentals........ & 97 & 42 & 139 & 69.7 & 30.2 \\
\hline *Nov. 27,1930 & 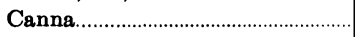 & 274 & 159 & 433 & 63.2 & 36.7 \\
\hline *Dec. 26,1930 & 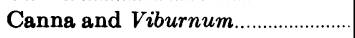 & 149 & 77 & 226 & 65.9 & 34.0 \\
\hline *Jan. 24, 1931 & Canna and Viburnum & 58 & 51 & 109 & 53.2 & 46.7 \\
\hline *Feb. 15,1931 & 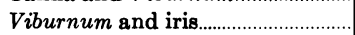 & 40 & 29 & 69 & 57.1 & 42.8 \\
\hline Mar. 21, 1931 & Prickly lettuce and sow thistle.. & 60 & 24 & 84 & 71.4 & 28.5 \\
\hline April 19, 1931 & Prickly lettuce... & 50 & 16 & 66 & 75.7 & 24.2 \\
\hline May 20, 1931 & 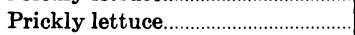 & 159 & 76 & 235 & 67.7 & 32.2 \\
\hline \multirow[t]{3}{*}{ June 22,1931} & Prickly lettuce................. & 80 & 28 & 108 & 74.0 & 28.9 \\
\hline & Totals........ & 1,260 & 639 & 1,899 & ......... & ........... \\
\hline & Average sex ratio............................. & ......... & ......... & $\ldots \ldots .$. & 66.3 & 33.6 \\
\hline
\end{tabular}

* Hibernating period. 
It will be seen that the sex ratio does not vary greatly in the greenhouse or in the laboratory from the ratio found to exist in the field under normal conditions. The seasonal variation, although not being great, demand some explanation and the following interpretation is suggested. Russell (1912b) thought that since the males were more active than the females they were not so often collected. However, the sex ratio determined from adults reared from confined larvae in the laboratory does not differ greatly from the average sex ratio of all the field collections and very closely approximates field collections made in the same month. It is difficult to explain why the collections made in January and February show a higher percentage of males since the males are normally shorter lived than the females and are apparently more easily killed by low temperatures. A high percentage of males is apparently not required in this thrips, as is the case in some insects, since the males are very active sexually and mate promiscuously. The normal sex ratio of females to males then is about 2 to 1 .

Power of Flight.-The power of flight is not so strong in the bean thrips as in many of the Terebrantia and consequently it does not migrate so readily as does the pear thrips or wheat thrips. The adult of fasciatus has, however, the power of hopping, and this capacity aids greatly in the dispersal of these insects. The wings of adults have been clipped off by the writer and the distance of the hops was never greater than 10 or 12 inches. Before taking off, the end of the abdomen is curled upwards which aids in spreading the wings, and then the insect springs nearly straight up into the air. Without the aid of the wind, the flight is zig-zag or spiral in manner and is usually not more than 3 or 4 feet in distance.

The manner of dispersal in the field is irregular, depending on the amount and direction of the air currents and the source of the original infestation.

Longevity of the Adult.-The length of life of the adult bean thrips varies with the season of the year. Hibernating adults live as long as five months and during the hottest part of the summer the average life of the adults in the field is about three weeks. Without food or water the average individual cannot live much longer than 24 hours and, with only water available, an occasional adult will live as long as six days. Newly emerged adults have been observed to exist as long as three days without food.

No actual counts were taken on the numbers of overwintering adults that survived, but during the winter of 1930-31 at Davis it is known 
definitely that hibernating adults lived at least five months. The length of the hibernating period will of course vary from year to year and no doubt certain overwintering individuals survive even longer.

The average length of life of 312 adults confined in cellophane cages on pears and beans was 22.1 days.

Also, mature larvae were collected in the field and allowed to pupate on the cotton plugs in shell vials in the laboratory. The adults upon emerging were retained in the vials either without water or with water made available by standing the vial upright in a dish of water, the cotton plug acting as a wick. This raised the humidity in the vial and the adults could obtain water by crawling down upon the saturated cotton. Food was made available to the thrips by the method described under "Rearing Methods and Technique." Of 89 newly emerged adults, the average length of life without food or water was 21.6 hours; and of 277 newly emerged adults, which were given water only, the average length of life was 4.6 days. The average length of life of the adult bean thrips was found to be 15.7 days, when given both food and water, in the laboratory under artificial conditions, which is somewhat shorter than in the field.

Hatching, and Activities of the Larva.-Bean thrips larvae have been observed to hatch from the egg on many occasions both in the daytime and at night. Previous to emergence, the egg seems to swell and give the appearance of a minute bump on the leaf. With magnification, the reddish-brown eye spots are often discernible through the egg shell. The egg shell splits lengthwise in the region of the thorax of the mature embryo. The back of the head and thorax of the emerging larva become visible first. The head is then pushed out of the shell and, by undulatory movements, the whole body is raised at right angles to the leaf surface. The emerging larva bends its body over sufficiently to grasp the leaf surface with its feet and pulls the tip of the abdomen entirely out of the egg shell. Feeding commences immediately.

Since the morphology of the mouth parts has not been studied in detail by the writer, it can only be said that, to all appearances, the mouth parts of the larva are similar to those of the adult. As was stated under the section "Nature of Injury" the larva does more feeding than the adult and is also inclined to feed in groups over a small area of leaf or fruit surface, thus leaving the silvery scars which are so characteristic of thrips' damage.

Distribution on the Host.-The majority of the larvae are found on the under side of the leaves of the hosts. Possibly they frequent the 
under side because the adult female finds the tissue here more favorable for oviposition or the larvae wish to avoid the direct rays of the sun. However, with the general observation in mind, counts were made to determine if such was actually the case. Of a total of 6,463 larvae counted on prickly-lettuce and pear leaves, 3,978, or 61.5 per cent, were found on the under side and the remainder on the upper side of the leaves.

In the case of heavily infested plants or terminals the larvae after having eaten over the entire under surface of the leaf will crawl onto the upper side and there complete their development. Thus, if counts were made from plants heavily infested with thrips early in the season, the majority of larvae would be found on the upper surface. However, under the usual conditions, the largest numbers of larvae are found on the under side of the leaves. In general, it might also be said that as the infestation works upwards on the host through the season, the majority of the large mature larvae are found on the lower leaves and the younger larvae and eggs on the upper ones.

The proportion of larvae to adults found on the host plants presents a condition which goes to show the great mortality present in the larval and pupal stages of this species of thrips. The subject of mortality will be found treated in another section and it is the purpose here to present the data obtained from field counts and observations on the proportion only.

Infestations of bean thrips were examined on pear foliage, beans, alfalfa, Swiss chard, sugar beets, and prickly lettuce, and counts were recorded of the numbers of larvae and adults present. Counts were made of the total number of thrips on individual plants and on individual leaves taken at random. Needless to say, during the fall, winter, and early spring such figures do not apply since there are no larvae between November and April. Over a period of three seasons, on various hosts and in three localities, the percentage of adults varied only from 14.4 per cent to 32.2 per cent. The proportion of larvae to adults on the plant is, then, about 5 to 1 .

Mortality of Mature Larvae, Prepupae, and Pupae in the Soil.-In making this detailed study of the life history of the bean thrips it was observed that, as is the case very often in nature, there is a very high mortality under natural conditions, and of the large numbers of individuals which are hatched, only a small number reach maturity and reproduce.

That such is true of the bean thrips is very clearly shown by daily counts and careful records kept over a period of nearly two months 
during the summer of 1930. A total of 9,143 mature larvae was obtained from the daily counts taken, and of this number 3,542 adult thrips and 83 parasites (Thripoctenus russelli $\mathrm{Cwfd}$.) emerged. These figures show a 60.3 per cent mortality (including 0.9 per cent parasitized) of those forms which were in the soil.

The greatest mortality occurs before the mature larvae transform to the prepupal stage. The prepupal stage contributes to the death rate, but to a lesser degree than the larval stage. In the pupal stage there is a slightly higher death rate than in the prepupal stage since the latter is very much shorter. Of a total of 624 mature larvae collected from host plants in the field and reared in the laboratory, 213, or 34.1 per cent, died before molting to the prepupal stage; 58 , or 9.3 per cent, died in the prepupal stage; and 103, or 16.5 per cent, died while in the pupal stage. From these figures we obtain a 59.9 per cent mortality, which is very close to that obtained from the field counts.

Some further attempts were made to determine the mortality of those stages which undergo a period in the soil. A wooden box, $12 \times 8$ inches and 8 inches deep, was filled with coarse soil and buried in the ground beneath a stand of prickly lettuce. The top of the box was made level with the surface of the ground and a wooden cover fitted tightly over it. A hole was bored in the cover through which a known number of mature larvae were introduced. A test tube was then inserted in this hole in the cover. The adults upon emerging are positively phototropic and crawl up into the tube towards the light and thus could be collected and counted. From 300 mature larvae employed, only 114 adults were obtained, thus giving a mortality of 62 per cent of the stages in the soil.

It is rather remarkable that the percentage of mortality in the field in 1930 , in the laboratory over a period of several months, and again in the field in 1931, are all so close, varying only from 59.9 to 62 per cent. It appears then that only about 40 per cent of the individuals becoming mature as larvae ever reach the adult stage and the counts illustrating the proportion of larvae to adults (which was found to be 5 to 1 ) point toward an even higher mortality.

Needless to say, before the larvae reach maturity and drop from the host, various predators, in addition to other factors, take their toll. 


\section{SEASONAL HISTORY}

The seasonal history of the bean thrips is not so narrowly defined nor so regular in its cycle as are certain other species of thrips, the pear thrips, for example (Cameron and Treherne, 1918). The generations are not clearly demarked and the seasonal activities as a whole are subject to considerable fluctuation depending upon the climatic factors and their degree of yearly variation. An account of the activities through the seasons can then, only in a general way, follow the insect through its yearly cycle. In addition to there being a yearly variation in the appearance and abundance of the bean thrips, its seasonal history varies to some extent in the different localities of its range, but we are here concerned with the conditions obtaining in central California.

The winter is passed in the adult stage on various host plants, preferably those remaining green throughout the colder months. This period of hibernation (November through March) is not one of complete inactivity. The adults are found singly or in groups on the under side of the leaves of various ornamentals or on filaree, lupine, poppy, miner's lettuce, and other native plants brought up by the first fall rains. The driving rains kill many of the overwintering individuals, unless well protected, by beating them off the hosts and trapping and drowning them among the lodged and sodden plants. During March, prickly lettuce, which is the favorite host, begins to appear and with the first warm days the survivors gradually migrate to this host and other early succulent plants such as sow-thistle and oftentimes alfalfa.

With the rising daily mean temperature $\left(55^{\circ}-60^{\circ} \mathrm{F}\right)$ of spring the adults begin to copulate and lay the eggs for the first generation. The adults continue to feed and oviposit for several weeks, but it is doubtful if many of them survive long enough to be included with the adults of the first generation and contribute to the second.

The length of the various stages in the life history and the number of generations were determined from cages placed on the host plants in the field.

The eggs, which are deposited in the leaf tissue require a long period of incubation, probably as much as 20 days, in the early spring. By the last of April larvae can be found in small numbers on prickly lettuce, filaree, California poppy, sow-thistle, etc., but the adults have become very scarce. The larvae mature in about three weeks and drop to the ground, crawl down cracks and openings in the soil to a depth of several inches and there transform. The prepupal and pupal stages together 
require 10 days or more. By the latter part of May the adults begin to appear in numbers to complete the first generation.

The newly emerged adults crawl up to the surface by way of the cracks and openings in the soil and find their way back onto the same wild plants and there lay the eggs for the second generation. The larvae of the second generation can be found about the first of June. The life of the adults during April and May is about four weeks and they continue to feed and oviposit over this entire period.

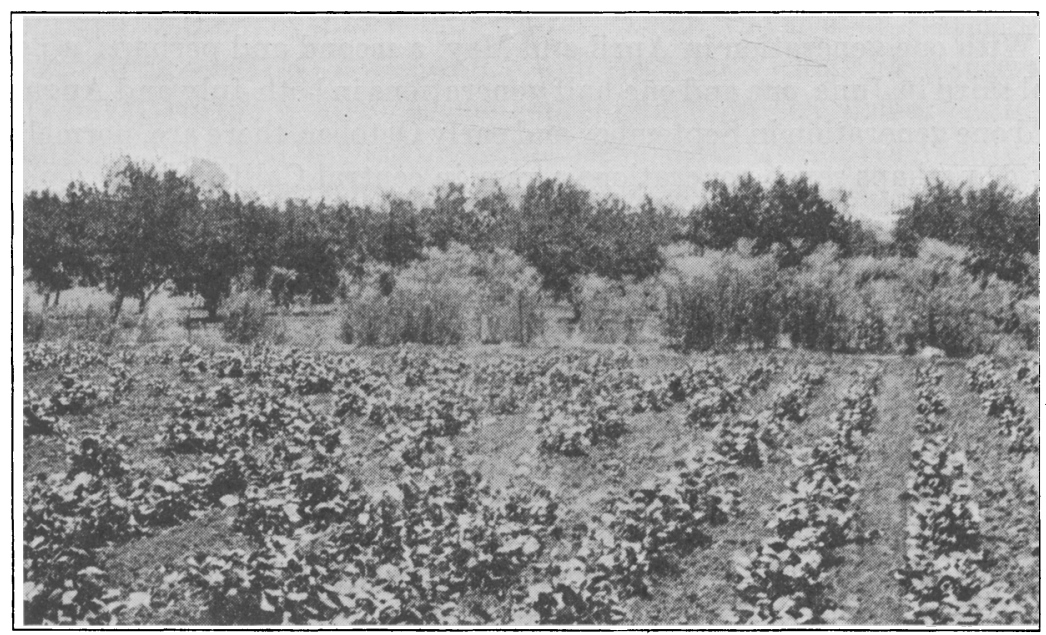

Fig. 5. Prickly lettuce between bean field and orchard providing favorable conditions for midsummer infestation of bean thrips.

The second generation completes its cycle in about a month, whereas the first generation requires about six weeks. From the first of June on, there is such an overlapping of generations that there are no marked broods.

During June, July, and August, a generation is completed about every three weeks. At the high summer temperatures (daily mean temperature of about $72^{\circ} \mathrm{F}$ ) the length of incubation of the egg is about 7 days, the first and second larval stages together extend over.about 10 days, and the pupal forms pass about 5 days in the soil.

Relatively few bean thrips are found on any plants in the summer other than prickly lettuce; i. e., where cultivated crops or ornamentals are not near by. About the first of July, this plant begins to throw out its inflorescence and the plant loses its succulence (fig. 5). The adults emerging at this time are forced to seek new hosts and there are to be found very few wild plants suitable. However, the variety integrata of 
Lactuca scariola germinates much later than the species and there is thus a scattering second crop of prickly lettuce. In addition, blazing star, Mentzelia laevicaulis, and a few other plants also serve as hosts during the late summer. The adults congregate upon these plants which are capable of supporting them through the late summer and early fall, provided, of course, crops are not at hand.

In September and early October there is another, the sixth, and possibly a partial seventh, generation. Shortly after the first of October the larvae disappear rapidly with the approaching cool, damp weather.

With one generation in April and May, a second and perhaps a partial third in June, one and one-half generations in both July and August, and one generation in September and early October, there are, normally, six or perhaps seven generations a year in central California.

The fall rains bring up a new crop of native plants, such as filaree, lupine, etc., which the remaining adults seek out and upon which they pass the winter.

There are two critical periods in the seasonal history of this thrips and they are both dependent on the amount of precipitation, which of course directly influences the abundance and condition of the native hosts. If the fall rains are either light or late in arriving, the adults have no succulent host capable of supporting them previous to hibernation and consequently suffer a high mortality. Again in the spring, in years of low rainfall, if there is no rain after March and the weather warms up rapidly, the wild plants are usually small and mature early. This results in a serious condition for the bean thrips, for even though a hot, dry climate is most favorable to the species, if the hosts are small and mature early, a high mortality prevails.

It is during dry years or in localities that present a semiarid condition normally that the bean thrips becomes of economic importance. When the native hosts begin to dry in early summer, the newly emerging adults at this time seek any other hosts available as beets, alfalfa, beans, pears, cotton, etc. The initial infestation builds up rapidly as the high mean temperature and low humidity make for ideal conditions for multiplication and by late summer severe damage results to such crops, particularly in nonirrigated sections.

A detailed study of the seasonal history of the bean thrips in pear orchards has been carried on during the past three seasons, and a brief account appropriately finds a place here.

The major portion of the work was done in the Berryessa Valley (Napa County), but additional information was obtained from pear- 
growing sections in Sacramento, Yolo, and Lake counties (Lewis, 1928, 1929, and Smith, 1930).

In the winter months the hibernating adult thrips are very difficult to find in the pear orchard environment. The floor of the orchard is at this time usually covered with a dense growth of weeds composing a covercrop. The few surviving adults are usually found on filaree and additional individuals often may be obtained from other weeds by general sweeping with a net. Almost invariably, wherever a prickly-lettuce plant is to be found, in thrips-infested localities, the adults are found congregated thereon in the late winter. About the last of March the covercrop of weeds is plowed under, and the adults which have successfully survived the winter become concentrated on any prickly-lettuce plants not destroyed by plowing in the orchards, and most frequently on those stands which so commonly spring up along the roadsides. The first and probably the second generations of the season are passed on these weeds.

From this point on, up to the time of the initial infestation of the pear trees, the activities of the thrips are difficult to follow accurately but an attempt is made here to analyze the succession of events at this time as brought out by varying local conditions.

In view of the facts that the early infestations are very local in the orchards and that the bean thrips has no strong powers of flight, migration from adjacent fields can perhaps be discounted. Also, there is no direct evidence that a prevailing wind is a factor of any great import in the distribution of this species of thrips.

It has consistently been apparent that the early infestations on the pear trees can be definitely correlated with the presence of wild hosts in very local areas. Those trees with limbs close to or actually touching the ground or those with sucker growth are the first to be infested. With the varying degree to which orchardists employ cultural practices, comparisons have been afforded in this study between orchards extremely well kept and those which have been somewhat neglected. From these comparisons it has been apparent that those orchards which were the most untidy in respect to weed growth, and those not well pruned, experienced the worst damage from bean thrips.

This matter of the presence or absence of weeds offers perhaps two possible explanations for the ultimate damage to the orchards. One explanation suggests that the early cultivation and removal of the prickly lettuce and other weeds forces the few adults present to migrate to the pear trees and, with an initial infestation of small numbers, some weeks are necessary for a sufficient population to build up to cause 
severe damage. On the other hand, if many wild hosts are present in and about the orchard, a large population of thrips builds up thereon (since the native hosts are preferred to the pear) and when these plants are killed, or mature, a forced migration to the pears takes place. Such an infestation takes place later in the season than in the case cited above, but the initial infestation in the second case is much greater and the damage, while showing up somewhat later, is more severe.

Whatever may be the exact succession of events, the thrips are usually found on the pear trees during the latter part of June. Throughout the following weeks the infestation which starts on the lowest branches gradually works upward and outward through the trees and by the last of the summer thrips are found, in severe cases, 15-20 feet high on the outermost terminals. In general, it is about the middle of July that the orchardists first notice the presence of the bean thrips on account of the dropping of dead leaves.

The third, fourth, and fifth generations and probably a partial sixth, depending on the season, are passed on the pear. By the first of October the leaves begin to fall and from then on the larvae disappear rapidly. The adults begin to seek out the remaining wild hosts as Lactuca scariola, Lupinus, and the first fall plants, chiefly filaree, on which to feed occasionally and subsequently pass the winter.

\section{PARASITES AND PREDATORS}

In spite of the abundance of the bean thrips and the habit of the larvae of feeding gregariously and unprotected on the leaf surface, the number or abundance of natural enemies is not great. We find representatives of six orders of insects, mites, and a nematode among the parasites and predators of Hercothrips fasciatus. Of the internal parasites there have been discovered to date only one hymenopteran, Thripoctenus russelli $\mathrm{Cwfd}$., and a nematode; these are both parasitic on the immature forms only. No secondary parasites have as yet been reported.

The larvae, being rather sluggish in their movements and unprotected by a heavy exoskeleton as are the adults, become the easy prey of their enemies. The adults, however, are not entirely immune from the attack of predators for, when the larvae are scarce, both the nymphs and adults of Orius insidiosus var. tristicolor White and the larvae of Aeolothrips fasciatus (Linn.) will prey upon the adult bean thrips. This was observed more commonly in the laboratory than in the field, since the larvae are seldom reduced sufficiently in numbers, with the exception 
of the spring and fall, to induce a condition where the predators are forced to feed on the adults.

In reviewing the literature on the Thysanoptera, we find listed as natural enemies : ladybird beetles-species of Megilla, Scymnus, and Hippodamia; of syrphid larvae-Syrphus and Sphaecrophoria sp.; Chrysopa spp.; Orius (Triphleps) spp., Anthocoris sp.; several predaceous thrips-Aeolothrips and Scolothrips sp. As internal parasites, there have been listed Thripoctenus spp., and Tetrastichus spp. In addition to the above-mentioned natural enemies, nematodes, fungi, mites, and spiders are of minor importance.

In central California during three seasons, the writer has made careful observations in the field and some studies in the laboratory to determine the relation between the bean thrips and certain insects commonly found associated with it. Only one internal parasite, Thripoctenus russelli Cwfd., has been found; the remainder are predators chiefly upon the immature forms and are the larva of Chrysopa californica Coq., Orius (Triphleps) insidiosus var. tristicolor White, both adult and nymph, the larva of Hippodamia convergens Guerin, the larva of Aeolothrips kuwanai Moulton (predacious on eggs and larvae), and the larva of Aeolothrips fasciatus (Linn.).

Adults of Orius tristicolor were placed with bean thrips which were confined in vials on prickly-lettuce leaves and observed over a period of weeks. Both the nymphs and adults attacked the smaller thrips larvae first, then the larger ones and finally the adults if no larvae remained. This predator is very active and may be seen to run up to a thrips and stick its beak into the head, thorax, or abdomen with no apparent aim. The struggling victim is often held down by the fore feet of the anthocorid, gradually the body of the larva may be seen to shrink and after 5 to 20 minutes, according to the size of the larva, the predator withdraws its rostrum and sets about cleaning its entire body. If disturbed while feeding, Orius will frequently run about or even fly with a thrips larva impaled on its needlelike beak. In the laboratory the adult predators consumed about one larva an hour and the nymphs appeared even more voracious. Sakimura (1930) reported that Orius tristicolor was predacious on the alfalfa thrips Frankliniella occidentalis (Perg.) to the extent of 26 to 33 per cent at Greenwood, Utah.

This anthocorid appears to prefer the larva of the common flower thrips to the bean thrips. However, since the flower thrips becomes greatly reduced in numbers during the hot summer weather, Orius is forced to feed upon the bean thrips in many localities. This predator winters over as an adult in rubbish and early in the spring they may be 
found feeding upon the larvae of the flower thrips. As the season progresses both the adults and nymphs become more abundant, and the eggs may be found in small yellowish-white clusters on the leaves of the host supporting the thrips. In the middle of the summer the bean thrips serve as food, and then again in the cooler weather of the fall, as the population of flower thrips builds up again and the bean thrips begin to disappear, Orius transfers its activities back to Frankliniella spp. The adult predators have lived as long as two weeks in confinement and the nymphal stage, during the summer, is about ten days. In certain localities this predator undoubtedly effects a considerable check on the infestation of bean thrips.

The larvae of Hippodamia convergens Guerin and Chrysopa californica Coq. in the spring may be found preying upon the first Hercothrips fasciatus larvae appearing, usually on prickly lettuce, sow-thistle, or alfalfa. These two predators do not seem to seriously affect the thrips populations and are of no great importance as natural enemies.

Of the predacious Thysanoptera two species have been found in the larval stage to prey upon the bean thrips. These two species are Aeolothrips fasciatus (Linn.) and Aeolothrips kuwanai Moulton. Adults of A. fasciatus confined in vials with bean thrips in the laboratory and in cellophane cages on the host plants in the field have never been seen to prey upon the bean thrips in any stage. The large yellow larva of $A$. fasciatus, however, are very voracious and inflict considerable damage in colonies of bean thrips larvae in the spring. Under confined conditions both larvae and adults of Hercothrips fasciatus are preyed upon. After the hot weather comes on, A. fasciatus can hardly be found. The larvae take two to three weeks to mature and, in the protection of curled leaves or debris near the host plants, they pupate. Very little is known further of the habits of this species. While it is common, no large numbers ever seem to be present and it is therefore not an important factor in reducing the bean thrips.

Likewise, the adult of Aeolothrips kuwanai has never been observed to prey upon the bean thrips either in the field or under artificial conditions. The long, slender, maroon-colored larvae, however, feed extensively on both eggs and larvae of Hercothrips fasciatus. On pears, prunes, and prickly lettuce, these predacious thrips larvae have been seen to walk about seeking the bean thrips eggs in the leaf tissue, and, upon finding one, to sink its mouth cone into the slight swelling raised on the leaf surface by the egg and suck up its contents. These larvae occasionally found their way into life-history cages and no bean thrips larvae hatched from such infested cages. In addition to feeding upon 
the eggs, they prey on the larvae but will not attack the adults. The pupae of Aeolothrips kuwanai transform on the host plant in curled leaves, abandoned spider webs, etc. While this species also is rather common, it never reaches the abundance necessary to be an important predator and is seldom seen at the height of summer when the bean thrips infestations are most severe.

The most important natural enemy of the bean thrips is probably the internal parasite Thripoctenus russelli. This parasite, a very minute chalcidoid of the subfamily Tetrastichinae, was first discovered by $\mathrm{H}$. M. Russell at Compton, California, in 1910 (Russell 1911, 1912a), and was described the following year by J. C. Crawford.

This parasite has not been studied in detail by the writer, but some interesting facts have been noted which add to what is already known of it. The adult parasites have been found during every month in the year in the open in association with the bean thrips. During the winter the adults have been found among the hibernating adults thrips on the under side of the leaves of various hosts. In the spring they are to be seen actively running about among the first generation of thrips larvae on prickly lettuce, filaree, sow-thistle, etc. During the summer they appear to be even more scarce than in the spring, but in September and October with the falling off of the thrips population there seems to be a sudden increase in the parasites.

This parasite has been observed to oviposit in the larger larvae only, and the act of oviposition required from 15 seconds to 4 minutes. On several occasions a parasite was seen to feed at the wound after ovipositing. Eggs are deposited both in the thorax and abdomen of the thrips larva but usually at the side of the abdomen. Attempts to oviposit are many times unsuccessful owing to the violent struggling of the larva. Parasitized larvae usually molt to the prepupal stage but never reach the pupal stage. The length of the egg plus the larval stage of the parasite averaged about 7.5 days while the pupal period averaged about 14 days during June and July, 1931. Adult parasites kept alive as long as 5 days at $30^{\circ} \mathrm{F}$ constant temperature were capable of ovipositing upon removal.

Russell (1912b) wrote that the parasitism of Hercothrips fasciatus in southern California ranged as high as 70 per cent. In central California the writer would estimate that there was, during the seasons of 19291931, very little over 5 per cent parasitism by Thripoctenus russelli; in fact, during June, July, and August, 1930, upwards of 10,000 thrips larvae were collected and counted and only 0.9 per cent parasitism was present. However, as was stated above, with the falling-off of the thrips 
population and the apparent increase of parasites, counts taken in the fall would have shown a much higher percentage.

It might be well to call attention to the fact that Bagnall (1913) reported T. russelli in England parasitic on Taeniothrips primulae, Physothrips atratus, Physothrips ericae, Oxythrips parviceps, Thrips tabaci, Thrips palustris, and Frankliniella intonsa. Cotterell (1927) wrote of a new chalcid parasite of the cacao thrips, Heliothrips rubrocincta (Giard), and his report of the habits of the parasite leads us to believe that it is Thripoctenus russelli or a very close relative. In addition there is a report by Waterson (1923) of an internal chalcid parasite, Tetrastichus thripophonus, of a thrips (no species given) in Trinidad, British West Indies.

Four species only of the suborder Tubulifera have been reported as parasitized. Williams (1916) described a new species of chalcid parasite, Thripoctenus nubilipennis, taken from Megalothrips spinosus and Cryptothrips rectangularis at Forest Hills, Mass. Mason (1922) reported a new parasite, an undescribed species of the genus Tetrastichus, from Cryptothrips laureli on bay trees in Florida. None of these parasites, even though so closely related, have as yet been reported from Hercothrips fasciatus or other members of its genus. Barnes (1930) described a new gall midge, Thripsobremia liothrips Barnes (Cecidomyidae), which is predacious on Liothrips urichi Karny in Trinidad. He wrote "This midge, besides being interesting because of its structural character, is noteworthy as being the second gall midge recorded as feeding on thrips. The other species is Adelgimyza thripidiperda Del Guercio, which is predacious on Phloeothrips oleae Costa, in Italy. This species was described (1918 and 1919) from the female and is only provisionally placed in the genus Adelgimyza."

Concerning the remaining natural enemies of the bean thrips-nematodes, fungi, mites and spiders-little can be said definitely. Russell (1912b) wrote that Mr. P. R. Jones had found a "nematode parasite working in the full-grown larvae of the bean thrips" at Lindsay, California. Fungi have often been observed attacking thrips in all stages, particularly under conditions of high humidity. However, the writer has never been able to determine whether the fungi attack the thrips while they are normally active or only after they have become weakened or have died. The latter is more probable.

Only two species of mites, Hypoaspis (Laelaps) macropilis Bks. and Anystis agilis Bks. have been reported from North America as preying on thrips. 
Adult bean thrips are very frequently found dead in spiders' webs on the host plants but no detailed study has been made of this relation and its proportional importance among the natural factors in reducing this thrips.

\section{EFFECTS OF TEMPERATURE AND MOISTURE ON THE LIFE STAGES}

Range of Activities of the Adult as Limited by Temperature.-The temperature range of various activities of the adult bean thrips was determined by placing the insects in an air-conditioning cabinet and varying the temperature at a constant rate of $1^{\circ} \mathrm{F}$ in three minutes. The humidity was held at $64 \pm 4$ per cent. The adults were collected from prickly lettuce and confined in glass tubes with cellophane caps over the upper end and prickly-lettuce leaves were used as food. The activities of the thrips were under continuous observation through the glass door of the cabinet. In one series of experiments the temperature was lowered until all adults became dormant and then raised again; in another series, the temperature was raised until the lethal point was reached. From 30 to 100 adults were used in each experiment. The "optimum" temperatures were considered to be those at which the greatest number of individuals exhibited activity. No data were obtained on the temperature range in which oviposition takes place since the bean thrips does not oviposit readily under artificial conditions. No relative differences in the activities of the sexes was noticed. (The males are at all times more active than the females.) The following tabulation gives a summary of the temperature range of various activities as determined under the above conditions.

\begin{tabular}{|c|c|c|}
\hline & $\begin{array}{c}\text { Temperature range } \\
\text { of activity }\end{array}$ & $\begin{array}{l}\text { Optimum } \\
\text { temperature }\end{array}$ \\
\hline Feeding.. & \multirow{7}{*}{$\begin{array}{cc}58^{\circ} \mathrm{F}-114^{\circ} \mathrm{F} \\
62^{\circ} & -116^{\circ} \\
70^{\circ} & -118^{\circ} \\
47^{\circ} & -120^{\circ} \\
117^{\circ} & \text {-death } \\
\ldots \ldots . & -45^{\circ} \\
118^{\circ} & -122.5^{\circ}\end{array}$} & \multirow{7}{*}{$\begin{array}{c}77^{\circ} \mathrm{F}-90^{\circ} \mathrm{F} \\
80^{\circ}-97^{\circ} \\
\text { No marked optimum } \\
\text { No marked optimum }\end{array}$} \\
\hline Copulation & & \\
\hline Hopping......... & & \\
\hline Crawling..... & & \\
\hline 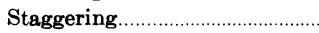 & & \\
\hline 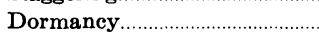 & & \\
\hline 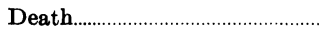 & & \\
\hline
\end{tabular}

The above data indicate that the activities of the adult occur over a wide range of temperature. There appears to be a tendency on the part of the adults to cluster when the temperature approaches that of dor- 
mancy but this activity was not considered marked enough to include in the data. The optimum temperature range of all activity is between $75^{\circ}$ and $90^{\circ} \mathrm{F}$. The age of the thrips was not considered in making these determinations, and in determining the lethal point the factor of time of exposure was not weighed.

Considerable variation among individuals was observed in the range of activities, but the figures presented are an index to the range of temperature in which feeding, sex activity, etc., take place. The limitations of activity as listed are not to be taken as inflexible since these experiments were conducted under artificial conditions. In the field, with its complex of environmental factors, marked variances would no doubt be found.

Effect of Temperature on Emergence of the Adult from the Soil.During the period from June 20, 1930, to August 9, 1930, daily emergence records were kept on the number of adults emerging from beneath each of four heavily infested prickly-lettuce plants which were kept under observation throughout the season. The plants were situated about 30 feet from the edge of a pear orchard. Closely woven white cloths, two feet square, were fitted tightly around the base of the plants and were weighted down along the edges with fine sand. At 7:00 A.M. and 5:00 P.M. each day the cloths were carefully rolled back and the newly emerged adults found clinging to the under side of the cloths were counted. (The adults were unable to penetrate the cloth or burrow out under the edges.) The mature larvae which had dropped from the plants onto the upper side of the cloths were first counted, and later, after the newly emerged adults had been counted, were placed on the soil and the cloths replaced. In this manner, over an area of 4 square feet beneath each plant, the daily emergence of adults was determined.

The infestation of thrips on these plants reached its maximum about July 11-15, and by the first of August the plants were flowering profusely and the population dropped off rapidly as a result of the loss of succulence.

A total of 3,542 adults was obtained from June 20 to August 9, 1930. The greater percentage of the adults emerged between the hours of 5:00 P.M. and 7:00 A.M. Of the total of 3,542 adults counted, 2,705, or 76.4 per cent, emerged between 5:00 P.M. and 7:00 A.M. There is no marked difference in the sexes in this reaction since, of a total of 2,505 females, 1,868 , or 74.6 per cent, emerged between $5: 00$ P.M. and $7: 00$ A.M.; and of a total of 1,037 males, 837 , or 80.7 per cent, emerged between 5 :00 P.M. and $7: 00$ A.M. Not only do the totals of the daily counts during this period show this to be the case, but the individual daily records also. 
The temperature of the soil at the surface apparently is an important factor and has a marked influence upon the emergence of the adults. During July and August, soil surface temperatures of $120^{\circ}-140^{\circ} \mathrm{F}$ during the day on unshaded areas are not uncommon and we have shown that such high temperatures are fatal to the adults; also, we have shown that no pupae survive within three inches of the soil surface if unshaded. It has been observed that when adults do emerge during the warmer parts of the day, they either succumb or immediately hop or fly onto the plants nearby and there find a temperature which is $20^{\circ}-30^{\circ}$ lower. On the other hand, the adults which emerge during the night, early morning, or evening do not so quickly seek the plants and remain resting quietly on the soil, crawl about slowly, and by a series of hops and flights reach the nearby plants. When such newly emerged adults are placed in the sun, they immediately become highly active and attempt to escape. It must be realized that often where the host plant is low or spreading, and thus shading the ground, the lethal soil surface temperatures are seldom reached. Furthermore, the counts and observations show that the majority of the adults emerge when the soil surface temperatures are such that they are enabled to safely gain the hosts.

The daily emergence records of adults throughout the period from June 20 to August 9, 1930, were plotted against the daily mean temperature and the curves smoothed by taking a five-day sliding average. There is, however, not nearly so close a correlation with the fluctuations in the mean temperature as was found in the case of the mature larvae dropping to the soil.

Rate of Egg-Laying as Influenced by Temperature.-The influence of temperature on egg-laying proved to be a very difficult point upon which to obtain any accurate data. The leaves of various hosts, as beans, pear, lettuce, beets, etc., were used, but none gave as good results as alfalfa, and it was found to be extremely difficult to make accurate counts of eggs in such a type of plant. Trouble was also had in keeping the cut leaves fresh enough to induce oviposition.

The information gathered on the effect of temperature on oviposition and the rate of egg-laying seems to be somewhat contradictory. In the field, oviposition has continually been observed most frequently in the morning between 7:00 A.M. and 9:00 A.M. and in the late afternoon. On the other hand, in the laboratory under controlled conditions the greatest rate of oviposition was found to obtain at $100^{\circ} \mathrm{F}$, at which temperature, however, all activity is greatly increased. This seemingly contradictory evidence would indicate that other factors are of more relative importance than temperature. 
In the experiment conducted to determine the effect of various constant temperatures on the rate of ovipostion the humidity was held constant at 40 per cent (with a fluctuation of 4 per cent) in each case. Pear leaves were used as a host plant and were changed as often as necessary, according to the temperature. The leaves were inspected daily under a binocular for eggs. The results are tabulated below:

\begin{tabular}{c|c|c|c}
\hline $\begin{array}{c}\text { Number of } \\
\text { females }\end{array}$ & $\begin{array}{c}\text { Duration of } \\
\text { experiment }\end{array}$ & $\begin{array}{c}\text { Temperature } \\
\text { (deg. Fahr.) }\end{array}$ & $\begin{array}{c}\text { Total number } \\
\text { of eggs laid }\end{array}$ \\
\cline { 1 - 2 } 40 & 20 days & 60 & 0 \\
40 & 16 days & 70 & 1 \\
40 & 10 days & 80 & 9 \\
50 & 10 days & 90 & 1 \\
25 & 12 days & 100 & 65 \\
\hline
\end{tabular}

Longevity of the Adult in Relation to Temperature.-The longevity of the adult bean thrips was determined at various constant temperatures and the results obtained seem to approximate very closely the conditions found in the field.

In this set of experiments an air-conditioning cabinet was used in which the temperature was held constant. The humidity was held at 40 per cent at each temperature. At temperatures above $50^{\circ} \mathrm{F}$, pear leaves were used as food; and at temperatures below $50^{\circ} \mathrm{F}$, no food was necessary since the thrips were inactive. Cold chambers in which the humidity was uncontrolled were employed in obtaining temperatures below $60^{\circ} \mathrm{F}$. The adults held at low temperatures were kept in shell vials and removed and counted twice a day-about five minutes being necessary for the survivors to warm up and become active enough to be separated from the dead. Table 4 lists the results.

TABLE 4

Longevity of Adult BeaN ThrIPs at Constant

TEMPERATURES

\begin{tabular}{|c|c|c|c|c|c|}
\hline \multicolumn{2}{|c|}{ Number of adults } & \multirow{2}{*}{$\begin{array}{l}\text { Tempera- } \\
\text { ture (deg. } \\
\text { Fahr.) }\end{array}$} & \multirow{2}{*}{$\begin{array}{l}\text { Average length } \\
\text { of life }\end{array}$} & \multicolumn{2}{|c|}{$\begin{array}{l}\text { Number of adults living } \\
\text { maximum time }\end{array}$} \\
\hline Males & Females & & & Males & Females \\
\hline 17 & 64 & 10 & 57.0 hours & 0 & 7 \\
\hline 101 & 267 & 30 & 104.6 hours & 2 & 17 \\
\hline 14 & 45 & 32 & 66.2 hours & $\mathbf{0}$ & 5 \\
\hline 36 & 69 & 40 & 267.0 hours & 3 & 13 \\
\hline 20 & 60 & 50 & 67.7 hours & 0 & 5 \\
\hline 29 & 45 & 62 & 72.0 hours & 0 & 7 \\
\hline 0 & 10 & 70 & 15.0 days & 0 & 2 \\
\hline 30 & 94 & 100 & 7.0 days & 0 & 16 \\
\hline
\end{tabular}


For inactive or hibernating individuals there appears to be an optimum survival temperature of about $40^{\circ} \mathrm{F}$. Constant temperatures below freezing produce 100 per cent mortality in 2-4 days. However, when held at temperatures above that which produced complete dormancy and below that producing normal activity, without food, the adults survive no more than 3 days. Then again, with food, higher temperatures (i.e., $100^{\circ} \mathrm{F}$ ) shorten their life as is usually the case when metabolism is markedly increased. The maximum length of life of 15 days was obtained at $70^{\circ} \mathrm{F}$.

In central California temperatures of $40^{\circ} \mathrm{F}$ and below are not normally experienced over any period of days and, under natural conditions, the hibernating thrips could no doubt easily survive much lower temperatures for a few hours. There are no data from laboratory experiments to support a comparison of the longevity of adults at constant and fluctuating temperatures. However, since the bean thrips is found in certain sections of Idaho and Utah having much lower mean winter temperatures than central California, it seems reasonable to believe that the adults can withstand much lower temperatures than these constant-temperature experiments indicate. There is no information on the place or manner in which the adults hibernate at high altitudes or in localities where severe winter conditions obtain. When they do survive, it is doubtless in extremely well protected situations and there is probably very high mortality.

Effect of Temperature on the Larval Stage.-The atmospheric temperature is one of the most important factors in the development and rate of growth of the bean thrips larva. Several weeks are necessary for the development of the larva in the spring and fall when the mean temperatures are considerably lower than during the summer, at which time the larval stage lasts only 10 days or less.

Newly emerged larvae and larvae that had just completed the first molt were used in these experiments. The larvae were obtained from a supply reared in the laboratory on pear and bean leaves as well as from prickly lettuce in the field. The rearing cage composed of a glass tube, cellophane cap, etc., as described previously, was used. Pear leaves were used as food, and some difficulty was experienced in keeping the leaves fresh at high temperatures. The glass tubes and leaves were inspected daily under a binocular for molted skins. The cabinet alone was employed in these experiments and the humidity was held constant in each case at 40 per cent. The results of these experiments are presented in table 5 . 
TABLE 5

EfFect of Temperature on the Larval Stage

\begin{tabular}{|c|c|c|c|c|c|c|}
\hline \multirow{2}{*}{$\begin{array}{c}\text { Number } \\
\text { of mature } \\
\text { larvae }\end{array}$} & \multirow{2}{*}{$\begin{array}{l}\text { Temperature, } \\
\text { (deg. Fahr.) }\end{array}$} & \multicolumn{2}{|c|}{ Average length of instars, } & \multirow{2}{*}{$\begin{array}{c}\text { Average } \\
\text { length of larval } \\
\text { stage, days }\end{array}$} & \multirow{2}{*}{$\begin{array}{c}\text { Per cent } \\
\text { total } \\
\text { development } \\
\text { per day }\end{array}$} & \multirow{2}{*}{$\begin{array}{c}\text { Average } \\
\text { mortality, } \\
\text { per cent }\end{array}$} \\
\hline & & First & Second & & & \\
\hline 60 & 60 & 18.0 & 15.0 & 33.0 & 3.3 & 57.0 \\
\hline 60 & 70 & 5.4 & 8.2 & $\begin{array}{l}13.6 \\
\text { S }\end{array}$ & 7.4 & 31.6 \\
\hline 65 & 80 & 5.0 & 4.0 & 9.0 & 11.1 & 21.5 \\
\hline 35 & 90 & 4.3 & 3.8 & 8.1 & 12.3 & 52.4 \\
\hline 45 & 100 & 3.0 & 2.0 & 5.0 & 20.0 & 81.5 \\
\hline
\end{tabular}

The lowest average mortality of 21.5 per cent occurred at $80^{\circ} \mathrm{F}$ and would perhaps indicate that this temperature is the most favorable to larval development.

The rate of development of the larva, as was true of the pupal stage, increased directly with an increase in the temperature. The theoretical zero point of development is at about $50^{\circ} \mathrm{F}$ (fig. $6, B$ ). In this graph, which illustrates the per cent of total development per day of the larva, the straight line is fitted by averaging the three lower points and the two upper ones and drawing the line through the points thus determined. The curve in figure $6, A$ was fitted to the length-of-stage curve by merely reading off and plotting the values from the straight line (fig. $6, B$ ) ; for example, at $80^{\circ} \mathrm{F}$ the percentage of total development per day is 10.5 per cent and it would thus take the larva 9.5 + days, theoretically, to complete its development while the experimental figure is 9 days. The rate of development is expressed after the manner used by Parker (1930). The circles represent the experimental data and the crosses the theoretical figures.

With these data, as with the data on the effect of temperature on the pupal stage, in the "reciprocal growth curve" (Sanderson and Peairs, 1913) a straight line was fitted to the per cent curve (fig. $6, B$ ) and the corresponding hyperbola fitted to the length-of-stage curve (fig. 6, $A$ ).

Effect of Temperature on the Dropping of Mature Larvae from the Host to the Soil.-It was observed from daily counts taken from July 20 to August 9, 1930, that the majority of the mature bean thrips larvae dropped from the host to the soil between 5 P.M. and 7 A.M. Heavily infested prickly-lettuce plants were the source of the counts, and cloths were spread beneath them to make the collection of the mature larvae possible. Counts were taken daily at 7 A.M. and 5 P.M. 
Of the total of 9,143 larvae counted over this period, 7,658, or 87 per cent, dropped to the ground between 5 P.M and 7 A.M. There was a downward trend in the daily counts as the result of the maturing of the host and the subsequent decrease in the thrips' population.

In order to determine more specifically during which hours the largest number of larvae drop to the ground, counts were taken every 2 hours for a 24 -hour period.
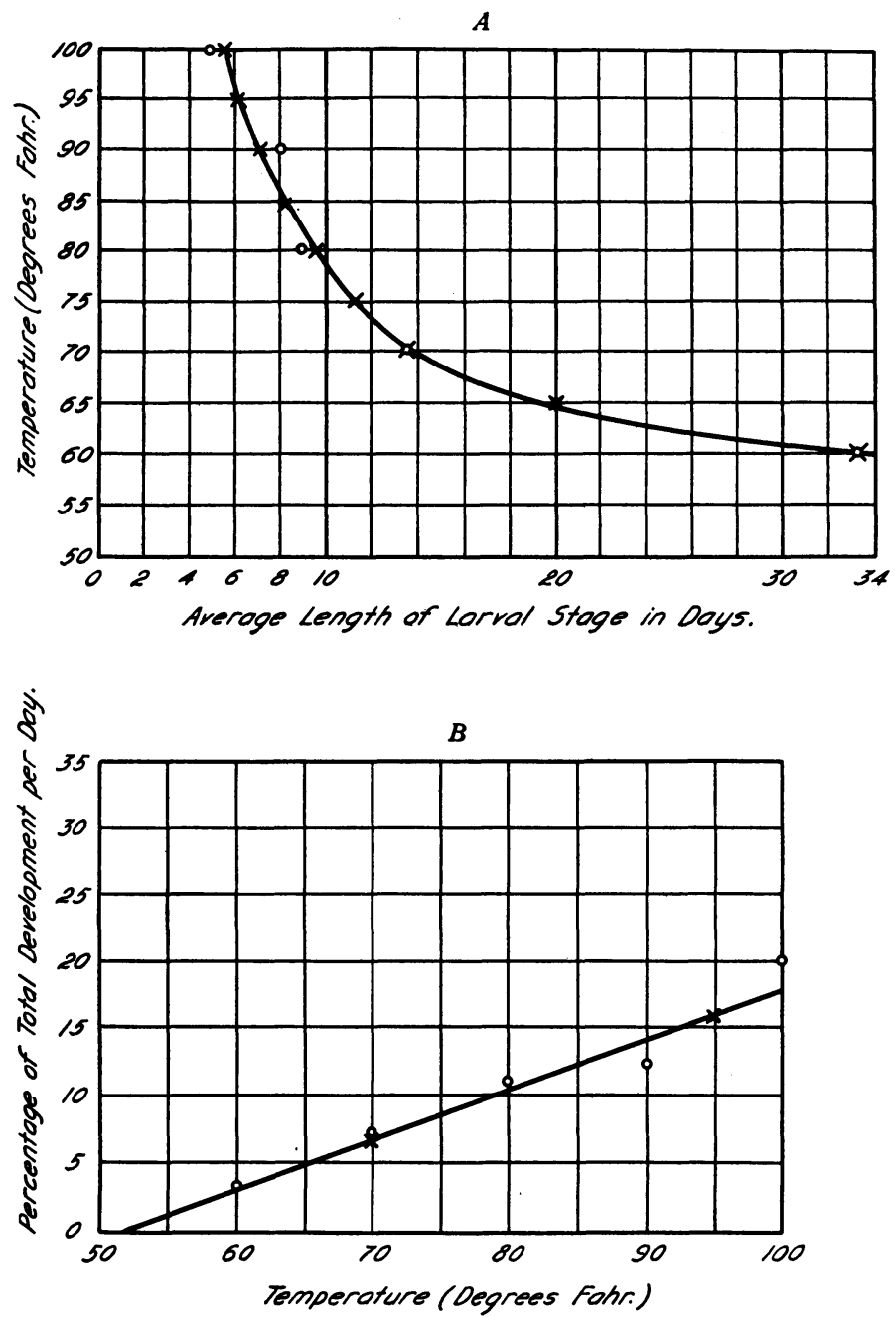

Fig. 6. Growth curves of the bean thrips. $A$, average length of the larval stage at various constant temperatures. $B$, per cent total development per day at various constant temperatures. The circles represent the experimental data and the crosses the theoretical figures. 
When the counts are represented graphically (fig. 7), it is more clearly seen that the largest number of mature larvae dropped to the soil between 6 P.M. and 10 P.M. and that a second and much smaller peak was reached between 6 A.M. and 10 A.M. From this, it appears that there was either an optimum atmospheric temperature between $65^{\circ}$ and $75^{\circ} \mathrm{F}$, at which the greatest number of mature thrips dropped from the host or a diurnal rhythm in respect to this activity. The soil-surface tempera-

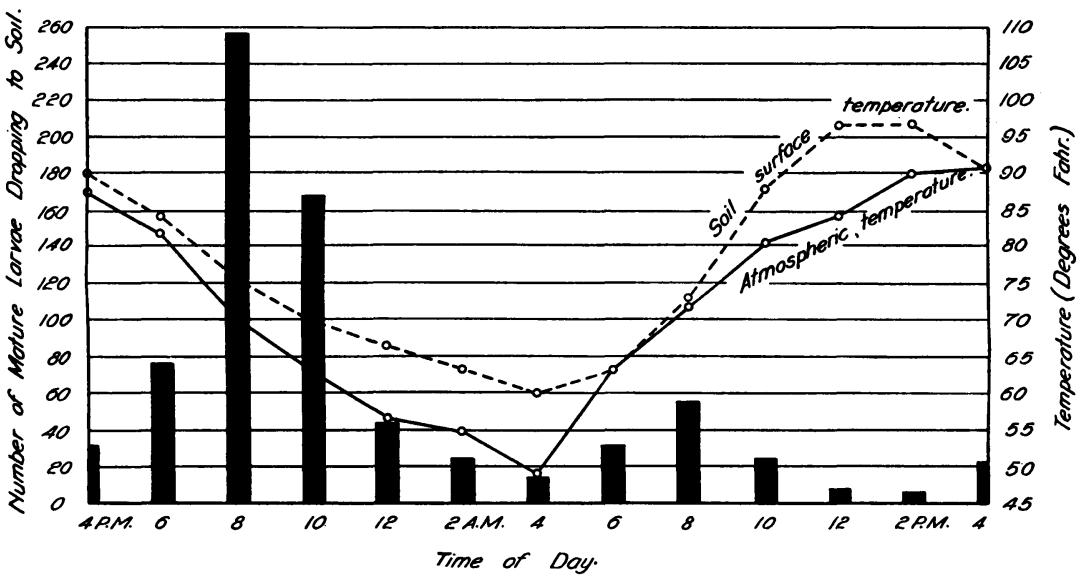

Fig. 7. Number of mature larvae dropping to the soil over a 24-hour period with atmospheric and soil-surface temperatures for period.

tures are given to show that at the time the majority of the larvae drop, temperatures lethal to them are not present at the surface of the ground and that sufficient time elapses for them to find a suitable place for pupation before the heat becomes too great.

Effect of Temperature on the Pupal Stage.-Temperature plays a most important part in influencing pupation, both as to the length of the stage and the rate of development, as well as the mortality occurring during this period.

The constant temperatures from $60^{\circ} \mathrm{F}$ to $110^{\circ} \mathrm{F}$ were obtained with an air-conditioning cabinet in which the humidity was held constant at $40 \pm 4$ per cent throughout the experiments. The constant temperatures below $60^{\circ} \mathrm{F}$ were obtained by the use of cold chambers in which the humidity could not be regulated. The mature larvae were collected in the field from the top of cloths spread beneath prickly-lettuce plants. The larvae were placed in vials and a cap of cellophane (No. 300 permeable) was stretched over the open end and held in place by an elastic band. The vials were examined daily and every few hours at the higher temperatures, under a binocular. The data obtained are given in table 6 . 
TABLE 6

Effect of Temperature on the Pupal Stage

\begin{tabular}{r|c|c|c|c|c|c}
\hline \hline $\begin{array}{c}\text { Number } \\
\text { of mature } \\
\text { larvae }\end{array}$ & $\begin{array}{c}\text { Tempera- } \\
\text { ture (deg. } \\
\text { Fahr.) }\end{array}$ & $\begin{array}{c}\text { Average } \\
\text { length of } \\
\text { prepupal } \\
\text { period, } \\
\text { days }\end{array}$ & $\begin{array}{c}\text { Average } \\
\text { length of } \\
\text { pupal period, } \\
\text { days }\end{array}$ & $\begin{array}{c}\text { Average } \\
\text { length of } \\
\text { orepupal and } \\
\text { pupal } \\
\text { periods, } \\
\text { days }\end{array}$ & $\begin{array}{c}\text { Per cent } \\
\text { total } \\
\text { development } \\
\text { per day }\end{array}$ & $\begin{array}{c}\text { Average } \\
\text { mortality, } \\
\text { per cent }\end{array}$ \\
\hline 50 & 28 & $\ldots \ldots$. & $\ldots \ldots$. & $\ldots \ldots$. & 0.0 & 100.0 \\
316 & 30 & $\ldots \ldots$. & $\ldots \ldots$. & $\ldots \ldots$. & 0.0 & 100.0 \\
50 & 40 & $\ldots \ldots . .$. & $\ldots \ldots .$. & $\ldots \ldots .$. & 0.0 & 100.0 \\
60 & 50 & 12.0 & $\ldots \ldots$. & $\ldots \ldots .$. & 0.0 & 100.0 \\
75 & 60 & 9.5 & 14.0 & .23 .5 & 4.2 & 94.0 \\
80 & 70 & 1.6 & 9.3 & 10.9 & 9.1 & 78.6 \\
100 & 80 & 1.0 & 3.0 & 4.0 & 25.0 & 50.0 \\
75 & 90 & 0.9 & 2.4 & 3.3 & 30.3 & 50.0 \\
108 & 100 & 1.0 & 1.8 & 2.9 & 34.4 & 65.7 \\
50 & 110 & 0.8 & $\ldots \ldots$. & $\ldots \ldots .$. & 0.0 & 100.0 \\
\hline
\end{tabular}

The rate of development is expressed after the manner used by Parker (1930), that is, as the percentage of a total development of the stage completed in one day of 24 hours. For example, if 5 days are required to complete the pupal stage at $85^{\circ} \mathrm{F}$ the rate of development at $85^{\circ}$ is 20 per cent of the total development per day. The length of the stage plotted against the temperature gives a typical growth curve (fig. 8, $A$ ). When the percentage of total development per day is plotted against the temperature (fig. $8, B$ ), the same type of curve is obtained as that termed a "reciprocal growth curve" by Sanderson and Peairs (1913).

It should be kept in mind that the bean thrips pupates in the soil and that soil temperatures are much more constant than atmospheric temperatures.

From the results it is apparent that the rate of development of the pupal stage increased directly with the temperature, from $60^{\circ}$ to $100^{\circ} \mathrm{F}$. Above and below this range 100 per cent mortality resulted while the lowest mortality prevailed equally at $80^{\circ}$ and $90^{\circ} \mathrm{F}$.

Depth of Pupation in the Soil and the Effect of Soil Temperatures on Pupation.-A careful inspection of soil beneath pear trees heavily infested with bean thrips revealed pupae, prepupae, and mature larvae at a depth of 3 to 6 inches. They were found in niches and cracks of the clumps of dirt, singly, and sometimes clustered together. The questions were then raised: how deep into the soil do the larvae make their way and is there an optimum depth which they seek?

Experiments were carried on both in the field and in the laboratory in an attempt to answer these questions. In all the experiments glass tubes with an inside diameter of $3 / 16$ inch were used. Tubes of lengths from 4 
to 15 inches were employed and individual tubes were filled entirely with fine or coarse soil particles or with a piece of roughly twisted string. The purpose of using the string was to serve as a support for the larvae in crawling downward, to insure an unobstructed path, and also provide suitable places in which to pupate. In all cases the tubes were placed vertically and cotton plugs were used at both ends. Mature larvae were collected in the field and introduced at the upper end of the tube. When the larvae were thus confined, the depth to which they crawled could be
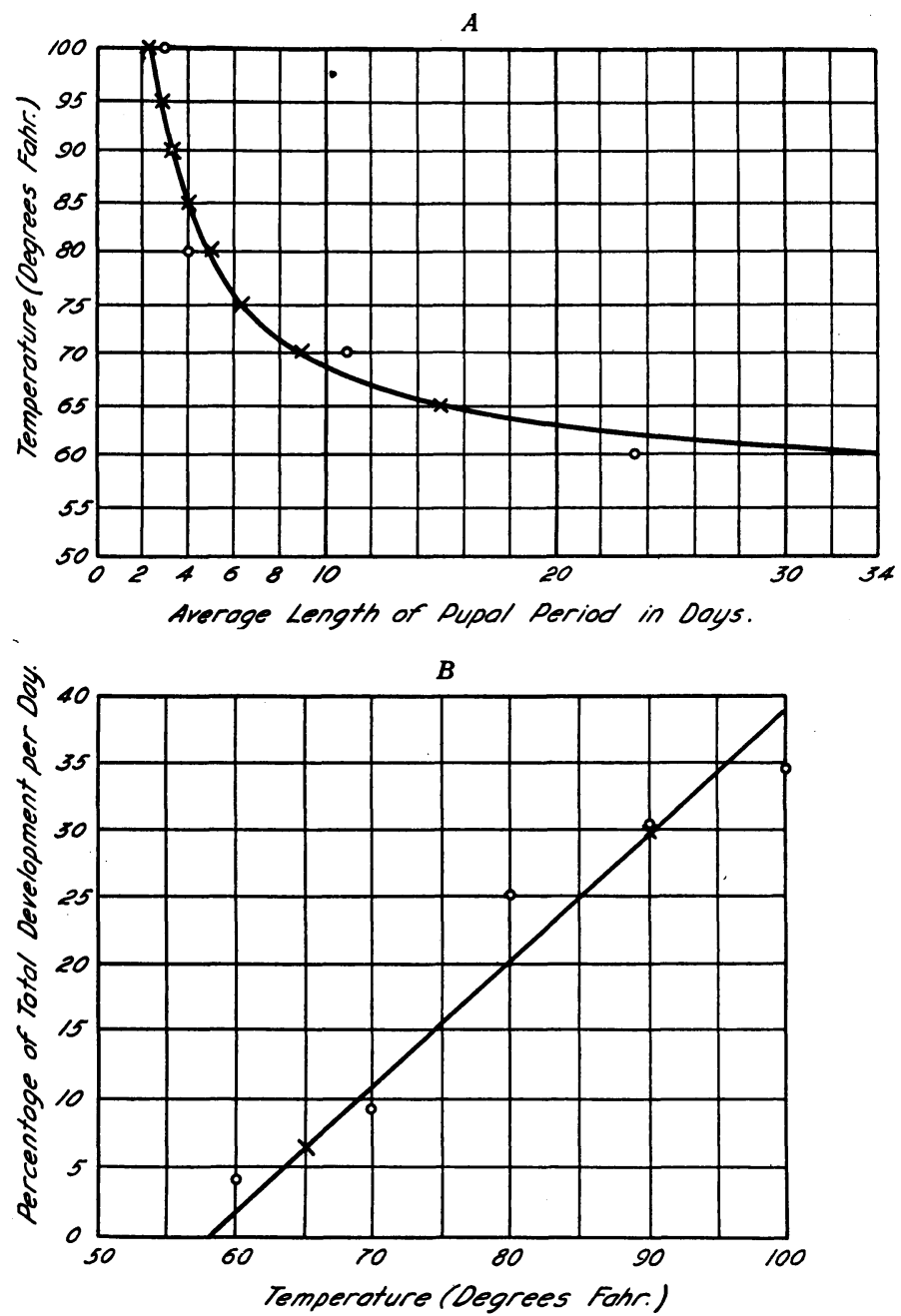

Fig. 8. Growth curves of the bean thrips. $A$, average length of the pupal stage at various constant temperatures. $B$, per cent total development per day at various constant temperatures. The circles represent the experimental data and the crosses the theoretical figures. 
measured, the number of larvae pupating at each depth counted, and the number of adults emerging recorded.

Fifty mature larvae were introduced into each of two tubes 6 inches long, one filled with fine, closely packed sand and the other with coarse, irregularly distributed particles of soil. These tubes were placed upright on a laboratory table and then covered to shut out the light. There was a high mortality among the group of larvae pupating in the fine sand. Five days later only 11 adults emerged from the tube containing sand. From the other tube which contained coarse soil, five days after the mature larvae had chosen their place of pupation, 31 adults emerged. This experiment was repeated several times and the results were the same in every case; i. e., the larvae could not penetrate the fine sand and there was a very high mortality; and, also, the larvae will crawl down among the soil particles until they reach an obstruction, whether it be $1 / 2,1,2,3$ inches, or more, at which point they will pupate.

Twenty prepupae were placed in a tube containing coarse soil and then observed. The prepupae, not being so active as the larvae, did not attempt to crawl down to the extent that the larvae did and came to rest in the first agreeable place that offered itself. No prepupae reached a depth greater than $1 / 2$ inch.

Two tubes, one 10 and the other 15 inches in length, with a piece of loosely twisted string running the entire length, were also employed. Fifty larvae were introduced into each tube. The majority of the larvae in each tube found their way to the bottom and there pupated in small groups in folds of the string. A few individuals were distributed the entire length of the tubes. The indication from these observations is that the mature larvae will crawl down until they find a place to their liking in which to pupate, irrespective of the depth, unless they meet with some obstruction.

In the orchard $3 / 16^{-i n c h}$ glass tubes of 5,10 , and 15 inches in length were used. These tubes were buried vertically with the upper end of the tube level with the soil surface. Either coarse soil or string was used within the individual tubes. As in the laboratory the larvae were found to make their way down to 15 inches depth or until their path became obstructed. Likewise, larvae were also found distributed the entire length of the tubes. Fifty mature larvae were used in each case and the experiment was repeated several times during July and August, 1930.

The outstanding observation was made that in no case did larvae attempting, or forced, to pupate within about 3 inches of the soil surface during these months, survive. 
A. Smith (1929) has shown that soil surface temperatures of $120^{\circ} \mathrm{F}$ are common during the summer months at Davis, California, and that at 3 inches below the surface temperatures of $90^{\circ}-95^{\circ}$ are fairly constant during the day. Thus it is not strange that bean thrips pupae seldom survive above in a depth of 3 inches in unshaded areas. Below this depth the mean daily soil temperature is considerably lower and subject to much less fluctuation which would provide a very suitable condition for pupation. It must be kept in mind, however, that where the soil is shaded by low or spreading plants that such lethal soil temperatures do not prevail and that pupation is possible very near to or even on the surface of the ground. This actually does occur, for pupae have been found in debris on the soil surface in dense stands of prickly lettuce.

Effect of Humidity on the Bean Thrips.-As is often the case in experimental work, it proved to be much more difficult to obtain data upon the effect of humidity than upon the effect of temperature on the insect. Also, normal activity seems to occur over a wide range of humidity, and it is only the condition of extreme dryness or of very high humidity that produces any marked effect on the various activities of the bean thrips. A high humidity is apparently unfavorable to this insect. Also it is in the summer when the rainfall is practically nil and in those localities where a minimum atmospheric humidity obtains that this thrips works its greatest damage.

Range of Activities of the Adult as Limited by Humidity.-In determining the effect of humidity on the activities of the adult the airconditioning cabinet was again employed and the insects were confined in vials on prickly-lettuce leaves in the same manner as was described above. No fewer than 100 thrips were used in each set of experiments. The temperature was held constant at $89^{\circ} \mathrm{F}$, which temperature favors all activity, and the wet-bulb temperature raised from $60^{\circ} \mathrm{F}$ to $88^{\circ} \mathrm{F}$ (giving an increase of relative humidity from 13.5 to 97.5 per cent) at the rate of $1^{\circ}$ rise of the wet-bulb temperature every 5 minutes. The "optimum" humidity, as was the case with optimum temperature, was considered to be the range in which the largest number of individuals were active. No oviposition took place during this series of experiments and no differences of note were observed in the activities of the females as compared with the males. In the tabulation below will be found the approximate limitations of the various activities.

It is apparent that humidity does not play such an important part in the activities of the adult thrips as does temperature. The humidity range within which the various activities were observed to occur is ex- 
tremely wide. The optimum atmospheric humidity for this insect appears to be somewhat less than 40 per cent, but in no case are the limits of activity so clearly marked as in the case of temperatures. This statement is based upon observations made in the field in addition to laboratory experiments.

\begin{tabular}{l|c|c}
\hline & $\begin{array}{c}\text { Range, per cent } \\
\text { relative humidity }\end{array}$ & $\begin{array}{c}\text { Optimum range, } \\
\text { per cent }\end{array}$ \\
\hline Feeding & $31.0-82.0$ & $31.0-68.0$ \\
Copulation & $13.5-97.5$ & $13.5-31.0$ \\
Hopping & $13.5-93.0$ & $13.5-31.0$ \\
Crawling & $13.5-93.0$ & $\begin{array}{c}\text { Uniform through- } \\
\text { out range }\end{array}$ \\
\hline
\end{tabular}

No deaths occurred on the part of any of the adults used in these experiments at either extreme of humidity. However, when the humidity was below 15 per cent all inviduals were highly active and more or less erratic in all their movements. On the other hand, when in a highly saturated atmosphere they became rather sluggish and exhibited no great activity of any nature.

Effect of Humidity on the Egg, Larva, and Pupa.-The egg more than any other stage in the life history requires a high and uniform humidity. As was stated above, the egg is deposited in the leaf tissue and in this environment it is constantly surrounded by a high humidity. It has been noted that when the water balance of the host plant is upset and plasmolysis results, the eggs within the leaf tissue fail to hatch. In addition to the loss of water, the shrinking tissues tighten around the egg and doubtless prevent hatching in event the embryo matures. When eggs were deposited on the leaf surface or even upon the wall of a vial, as has happened in the laboratory on several occasions, they slowly shriveled up and never hatched. The chorion is very delicate and when thus exposed desiccation proved fatal.

Experiments conducted under controlled conditions indicated there was apparently no effect on the rate of development of the larva in the range from 22 to 60 per cent relative humidity (the temperature being constant at $90^{\circ}$ and $100^{\circ} \mathrm{F}$ ). Such a variation in humidity might have some effect at lower temperatures, but it is very doubtful. The average length of the first larval instar at $100^{\circ} \mathrm{F}$ was three days both at 22 and at 60 per cent relative humidity, and the average length of the second instar was two days. At a constant temperature of $90^{\circ} \mathrm{F}$, and at both 22 and 60 per cent relative humidity, the average lengths of the first and second larval instars were 4.3 and 3.8 days, respectively. In addition 
to there being no noticeable change in the rate of development or length of instars there was no apparent effect of a 38 per cent change (22-60 per cent) of humidity upon the feeding or general activity of the larva.

Under normal conditions the atmospheric humidity does not play a direct part in the environment of the pupa and the matter of moisture is governed by the percentage of moisture in the soil. No attempt has been made in these studies to determine the effect of soil moisture upon the pupa but a small amount of data has been obtained upon the effect of various constant humidities.

Constant humidities of 22,40 , and 95 per cent were obtained with an air-conditioning cabinet and the temperature was held constant at $100^{\circ} \mathrm{F}$ in each experiment. The mature larvae were collected and confined in the manner previously described. Fifty larvae were used in each experiment. The average length of prepupal period was one day and for the pupal period two days at all humidities. The average mortalities at 22,40 , and 90 per cent humidity were $50.0,65.7$, and 61.0 per cent, respectively.

Humidity had very little effect on the length of the pupal stage at $100^{\circ} \mathrm{F}$, and the variation in the percentage of mortality at the different humidities is not particularly significant.

Another type of experiment was tried in which $3 / 16^{\text {-inch glass tubes } 6}$ inches in length were filled with coarse dirt and plugged with cotton at both ends. Mature larvae were introduced at one end and were allowed to seek out suitable places in which to pupate. The tubes were then placed upright in a shallow dish of water. The water rose slowly, saturating the soil and thoroughly wetting the mature larvae and prepupae. Puddling the soil resulted in trapping many individuals in droplets of water and thoroughly coating them with mud. The majority of those in direct contact with water died in about 24 hours and began to disintegrate rapidly while many others were attacked by a fungus. A total of 120 mature larvae were used and by the end of six days all were dead, only 12 transforming to the prepupal stage.

Resistance of the Adult to Submergence in Water.-The adult bean thrips is somewhat resistant to submergence in water and can remain alive for as long as one hour when completely submerged. Some experiments were conducted to determine the resistance of the adults to water. Ten adults were placed in each of six vials which were filled with tap water and inverted. The thrips were observed to crawl around on the bottom and up and down the sides of the vials while completely submerged. Small bubbles of air clung to the hairs of the body and to the 
wings. They gradually became weaker and succumbed-two individuals surviving as long as one hour under water. The adult thrips swims readily on the surface by fanning the wings and moving the legs and could easily gain the sides of the vial or petri dish and clamber out unless forcibly submerged in some manner, so in the above experiments a layer of cotton was placed on the surface of the water.

In addition to the above experiments the adult bean thrips were studied in the field during a drenching rain. The beating action of the rain appears to be responsible for the heavy mortality that occurs in the field after a storm. A driving rain washes the adults off the leaves onto the ground. They can also be found dead, adhering to the wet leaf surface and actually in drops of the rain water remaining on the plant. If thoroughly wet, the wings become stuck together and cannot be extended until they are dried. When in or on the ground a thrips adult quickly becomes embedded in the mud or crushed by the shifting and settling of the soil particles.

\section{SUMMARY}

The bean thrips was first collected in Yuba County, California, in November, 1894. Its original home is unknown.

The known distribution records include Mexico, Brazil, China, and the following states in North America: California, Nevada, Idaho, Arizona, Texas, Louisiana, Alabama, Florida, and South Carolina.

The primary injury done by Hercothrips fasciatus is the extraction of fluids from the host plants which, in nonirrigated localities and at high temperatures, results in the rapid desiccation of the injured tissues.

The host list includes many native plants and crops. The favorite wild host is the prickly lettuce, Lactuca scariola, and the crops most commonly injured are beans, cotton, and pears.

Winter is passed in the adult stage chiefly on the under side of leaves of plants remaining green and offering protection.

The method of reproduction is both bisexual and parthenogenetic; fertilized eggs produce females and unfertilized eggs males. The normal sex ratio of females to males is about 2 to 1.

About the last of March the overwintering adults migrate to prickly lettuce, sow-thistle, etc., and two generations are usually passed on these native hosts in April, May, and early June. During midsummer a generation is completed in about three weeks. There are, then, from April to October, six or seven generations, according to the monthly mean temperature. 
With the drying-up of the native vegetation the bean thrips is forced to seek new food plants and thus about the last of June, or in early July, crops become infested.

The eggs are inserted in the plant tissue and appear as minute bumps on the leaf surface. The larva has two stages, molting but once on the host. Upon maturing, the larva drops to the ground and seeks a suitable niche in the soil in which to pupate. The depth of penetration depends on the type and structure of the soil. The mature larva after molting enters a short prepupal stage in which the wing stubs become visible. The prepupa molts and then enters the true pupal stage. In the prepupal and pupal stages the insect is mobile but takes no food. After casting the pupal skin the sexually mature adult, fully winged and pigmented, finds its way to the surface via the openings in the soil. The hosts are gained by short hops and flights.

During the summer months, in central California, the length of the egg stage is about 7 days, the first and second larval stages together are about 10 days, and the pupal forms pass about 5 days in the soil. The preoviposition period is about 3 or 4 days.

The natural mortality of the immature stages is about 60 per cent.

There is only one known internal insect parasite of the bean thrips; namely, Thripoctenus russelli Cwfd. The chief predator is Orius insidiosus var. tristicolor White. Aside from these, the other natural enemies have little affect on the normal thrips population.

The adults are active between about $50^{\circ} \mathrm{F}$ and $117^{\circ} \mathrm{F}$, the optimum range of activity being between $75^{\circ} \mathrm{F}$ and $90^{\circ} \mathrm{F}$.

The rate of development of the larva, as is true of the pupal stage, increases directly with an increase in temperature. The theoretical zero point of development is at about $50^{\circ} \mathrm{F}$.

The majority of the larvae drop from the host to the soil at a time when temperatures lethal to them are not present at the surface of the ground.

Pupae seldom survive in the soil in unshaded areas if they have not penetrated at least 3 inches beneath the surface.

The relative humidity range of adult activity is very wide; the optimum appears to be somewhat less than 40 per cent.

Both pupa and adult are comparatively susceptible to drowning. 


\section{ACKNOWLEDGMENTS}

To Dr. Stanley B. Freeborn, the writer wishes to express appreciation for fore-sighted guidance and timely counsel in directing the major part of this investigation. The advice of Dr. E. C. Van Dyke and Professor E. O. Essig in directing certain phases of the work has been invaluable. Professor W. B. Herms, Dr. T. I. Storer, and Dr. W. C. Cook have made many suggestions which have aided very materially in the preparation of this paper. The writer is indebted to Mr. L. M. Smith for his cooperation in carrying on some of the field studies. 
BAGNALL, R. S.

\section{LITERATURE CITED}

1913. A chalcid parasitic on thrips (Thysanoptera). Rpt. Brit. Assoc. Adv. Se. p. 531.

BAILEY, S. F.

1931. The use of transparent cellulose films in life history studies. Jour. Econ. Ent. 24:898-901.

1932. A method employed in rearing thrips. Jour. Econ. Ent. 25:1194-1196.

BARNES, H. F.

1930. A new thrips-eating gall midge, Thripsobremia liothrips. Bul. Ent. Res. 21:331-332.

BONDAR, G.

1924. Thrips de alfalfa e ervilha (Heliothrips fasciatus Pergande). Carreioagricola 2:112-113.

BREMner, O. E.

1910. Destructive insects and their control. California State Comm. Hort., 4th Bien. Rpt. p. 20.

BuFfa, $P$.

1911. Studi intorno al ciclo parteno-genetic dell' Heliothrips haemorrhoidalis (Bouché). Redia 7:71-109.

Cameron, A. E., and R. C. Treherne.

1918. The pear thrips and its control in British Columbia. Dominion of Canada Dept. Agr. Ent. Bul. 15:7-41.

CotTerell, G. S.

1927. A new parasite of Heliothrips rubrocincta. Gold Coast Dept. Agr. Bul. 7:47-48.

Crawford, D. L.

1909. Notes on California Thysanoptera. Pomona Jour. Ent. 1:120-121.

CRaWFord, J. C.

1911. Two new Hymenoptera. Proc. Ent. Soc. Wash. 13:233.

DANIEL, S. M.

1904. New California Thysanoptera. Ent. News 15:293-297.

DAvidson, J., and J. G. BALD.

1930. Description and bionomies of Frankliniella insularis (Franklin) (Thysanoptera). Bul. Ent. Res. 21:365-385.

1931. Sex determination of Frankliniella insularis. Austral. Jour. Exp. Biol. Med. Se. 8:139-142.

EdDy, C. O., and E. M. LivingSTone.

1931. Frankliniella fusca Hinds (Thrips) on seedling cotton. South Carolina Agr. Exp. Sta. Bul. 271:5-23.

Essig, E. O.

1915. Injurious and beneficial insects of California (2nd ed.). California Hort. Commission. p. 51-53.

1926. Insects of western North America, p. 183-184. Macmillan Co. 
Foster, S. W., and P. R. Jones.

1915. The life history and habits of the pear thrips in California. U. S. Dept. Agr. Bur. Ent. Bul. 173:38.

Hinds, W. E.

1902. Contribution to a monograph of the insects of the order Thysanoptera inhabiting North America. Proc. U. S. Natl. Mus. 26(1310) :82, 174-175.

Hood, J. D.

1927. New neotropical Thysanoptera collected by C. B. Williams, Part II. Psyche $34: 230-246$.

JoHN, O.

1923. Fakultative viviparitat bei Thysanopteren. Ent. Mitteilungen. 12:227232.

LEwIS, H.C.

1928. Seasonal insect control notes-bean thrips on pear. California State Dept. Agr. Mo. Bul. 17:209.

1929. The bean thrips on pear. California State Dept. Agr. Mo. Bul. 18:52-58.

Mason, A. C.

1922. Cryptothrips laureli, a new thrips from Florida (Thysanoptera). Ent. News 33:193-199.

Moulton, D.

1907. A contribution to our knowledge of the Thysanoptera of California. U.S. Dept. Agr. Bur. Ent. Bul. Tech. Ser. 12(3):52.

1911. Synopsis, eatalog, and bibliography of North American Thysanoptera. U. S. Dept. Agr. Bur. Ent. Bul. Tech. Ser. 21:23.

PARKER, J. R.

1930. Some effects of temperature and moisture upon Melanoplus mexicanus mexicanus Saussure and Camnula pellucida Scudder (Orthoptera). Univ. Montana Bul. 223:5-132.

Pergande, T.

1895. Observations on certain Thripidae. U. S. Dept. Agr. Insect Life 2:391. Peterson, A.

1915. Morphological studies on head and mouthparts of the Thysanoptera. Ann. Ent. Soc. Amer. 8:20-67.

Pomerrol, $R$.

1928. Parthenogenesis in Thysanoptera: maturation of parthenogenetic eggs of H. haemorrhoidalis. Bul. Biol. France and Belg. 62:1-20.

Priesner, H.

1926. Die Thysanopteren Europas. Obteilung 1 and 2, p. 1-343. F. Wagner, Wein.

Radulesco, E.

1930. Quelques observations biologiques sur Parthenothrips dracaenae Heeg. et Aptinothrips connaticornis Uzel. Rev. Path. Veg. et Ent. Agr. 17:24-28.

RAYMOND, G.

1924. Contribution à l'étude des thrips attaquant les oeillets. Soc. Linne. de Lyon, n.s. 70:160-172. 
RUSSELL, H. M.

1911. A true internal parasite of Thysanoptera. Proc. Ent. Soc. Wash. 13: 235-238.

1912a. An internal parasite of Thysanoptera. U. S. Dept. Agr. Bur. Ent., Tech. Ser. 23(2):25-52.

1912b. The bean thrips. U. S. Dept. Agr. Bur. Ent. Bul. 118:7-45.

1912c. The red-banded thrips. U. S. Dept. Agr. Bur. Ent. Bul. 99(2):17-29.

SAKIMURA, K.

1930. A predacious mite on the alfalfa thrips. Jour. Econ. Ent. 23:1009.

Sanderson, E. D., and L. M. Peatrs.

1913. The relation of temperature to insect life. New Hampshire Agr. Exp. Sta. Bul. 7:3-41.

SHULL, A. F.

1914a. Biology of the Thysanoptera. Amer. Nat. 48:161-176, 236-247.

1914b. Parthenogenesis in Anthothrips verbasci. 16th Ann. Rpt. Mich. Acad. Se. p. 46-48.

1915. Parthenogenesis and sex in Anthothrips verbasci. Science, n. s. 41:442.

1917. Sex determination in Anthothrips verbasci. Genetics 2:480-488.

SмIтн, A.

1929. Daily and seasonal air and soil temperatures at Davis, California. Hilgardia 4(3):77-112.

Sмгтн, L. M.

1930. The bean thrips on pears. Blue Anchor 7:15-16, 31-34.

Steinweden, J. B., and D. Moulton.

1930. Thysanoptera from China. Proc. Nat. Hist. Soc., Funkein Christ. Univ., China. p. 1.

W ARdLe, R. A., R. Simpson, and E. MacGill.

1927. Biology of Thysanoptera with reference to the cotton plant. Ann. Appl. Biol. 14:482-528.

WATERSON, J.

1923. On an internal parasite (Mym. - Chalcidoidea) of a thrips from Trinidad. British West Indies Bul. Ent. Res. 13:453-455.

WATson, J. R.

1923. Synopsis and catalog of the Thysanoptera of North America. Florida Agr. Exp. Sta. Bul. 168:6-24, 35.

1926. Ecological and geographical distribution of Thysanoptera in Florida. Florida Ent. 10:21-24, 27.

White, W. H.

1916. The sugar-beet thrips. U. S. Dept. Agr. Bul. 421:5, 10.

WHTTNEY, L. A.

1930. Report of the associate plant inspector, 1929. Hawaiian Forester and Agr. 26:199-200.

WILliams, L. T.

1916. A new species of Thripoctenus (Chalcidoidea). Psyche 23:54-61.

Yothers, W. W.

1924. The camphor thrips. U. S. Dept. Agr. Bul. 1225:16. 